\title{
7
}

\section{Novels and Buildings}

\section{Novels}

\section{Gli indifferenti: The Reconstruction of the Novel}

When it appeared in 1929, Gli indifferenti was hailed as an example of the new realism that was at the centre of debates in literary and cultural journals (see Chaps. 3, 5 and 6; see also Ben-Ghiat 1995, 641; 2001, 57; Buchignani 2012, 68). Moravia started publishing short stories in 900 in 1927, which suggests that the young writer shared, or at least felt close to, the journal's programme (see Chap. 5). ${ }^{1}$ In 1928 he also published several short stories in the Fascist avant-garde magazines I lupi and Interplanetario. ${ }^{2}$ These writings anticipated Gli indifferenti with their narrative strategies, specifically the restoration of the function of characters, and the attempt at striking a balance between action and psychological analysis (see Carpi 1981b). Moravia theorized these aesthetic strategies as the necessary response to a perceived 'crisis of the novel', in an article he wrote in 1927 for the magazine La fiera letteraria, entitled 'C'è una crisi del romanzo?'3 In this article, like many other authors and critics at this time, Moravia blamed the crisis of the novel on its excessive psychologism, which caused 
concrete reality to dissolve into pure thoughts and introspection-what he called the novel's 'psychoanalytic dead weight' ('zavorra psicoanalitica'). Moravia located the problem in an imbalance between plot and psychological introspection, which needed to be redressed. He did not suggest returning to 'pure' action or pure description, which would imply a regression towards a traditional, naturalistic structure. Rather, novelists should seek to strike a balance between the dimension of action and that of consciousness. One way to do this was rehabilitating the mediating role of characters, who would no longer be reduced to mere sequences of thoughts and consciousness (see Voza 1997, 12-13). Moravia complained that too many Italian authors were far from producing 'a true and convincing representation of life' ('una rappresentazione vera, e soprattutto convincente della vita') (Moravia 1927, reprinted in Voza 1982, 211).

In Gli indifferenti, Moravia achieved this on a formal level through his recourse to a third-person, partially omniscient narrator, in what has been defined by critics and by the author himself as a 'theatrical novel' (Schettino 1974). The effect of this type of narration is to underscore the autonomy of the characters and the distance that exists between them and the narrator. Commenting on Gli indifferenti many years later, Moravia said that he had intended to write a novel that would simultaneously possess the qualities of a work of fiction and those of a play-thus, a novel with a rationalized narrative structure, in which the characters would emerge as strong and independent, and the author would practically disappear:

A novel with few characters, with very few settings, with its action unfolding over a short time. A novel with nothing but dialogues and background details, in which all the commentaries, analysis and interventions of the author would be carefully abolished to create a perfect objectivity. [...] Besides, I had convinced myself that it was not worth writing if the author did not compete with the Creator in the invention of independent characters, living a life of their own. (Moravia 1964, 63-64) ${ }^{4}$

Moravia explains here how the mutual interferences between the genres of fiction and drama have an important role in the work's gestation. However, his comments also relate to his involvement in the project of 
reconstructing the novel, already discussed in his abovementioned article, which was based on some of the principles that we have discussed in previous chapters. These principles were what united the novel and architecture in their efforts to effect aesthetic renewal under the Fascist regime: the rationalization of forms, an adherence to reality, and the construction of 'objects' which were detached and independent from the subjectivity of the author. A drive for positive reconstruction underpinned these artistic undertakings, which reflected, and often actively supported, the regime's anthropological enterprise of forging a new culture and a new civilization. In his article, Moravia stated his commitment to this constructive effort-which defined the spirit of that era-by denouncing a 'pathology' affecting the novel (by implication, something that can be cured, and is reversible), and identifying ways to take 'restorative' action (Moravia 1927, reprinted in Voza 1982, 210-12).

The first reviewer of Gli indifferenti was the writer and literary critic Giuseppe Antonio Borgese, who in 1923 had written an article with the revealing title of Tempo di edificare (Time to build). In this important essay, he called for a new, constructive literature removed from the dominant 'fragmentism' famously championed by the early twentieth-century literary journal La Voce, and a return to long, well-structured and fully developed novels, which would contribute to the building of new values for a modern society (see Chap. 3). Unsurprisingly, Borgese wrote a positive review of Gli indifferenti, published in Il corriere della sera on 21 July 1929 (reprinted in Borgese 1962, 214-20), in which he lauded the qualities of a novel which was contributing to the reconstructive effort which he had himself called for a few years earlier. Borgese praised the novel's broad and 'solid' structure, the rationalized narration, the vigorous and 'healthy' prose (which he compared to strong, vigorous brush strokes in painting), and its simplified, sparse style. The language used, he claimed, was 'beautiful, because it is purged of any embellishment' ('un'arte di scrittura molto bella, perché depurata di ogni belluria [...]'). It exemplified a much-needed clean break with the excessively ornate and flowery style of those writers that Borgese himself had called 'calligraphic', a tendency which according to him and many other critics had ruined Italian prose and poetry. In Gli indifferenti, Borgese argued, the writer's concern was not for the elegance of single words or fragments, but rather for a 
large-scale, natural and cohesive narration, whose overarching effect was one of 'soundness and vigour' ('sanità', [...] vigore'). Accordingly, the plot was stripped down to material facts and reduced to what read like a news story. This comment, in particular, is reminiscent of Bontempelli's advice for writers (see Chap. 5, pp. 101-102).

Borgese's comments highlighted and praised an extreme rationalization and simplification of both the contents and the form of the novel, matched by an almost disturbing adhesion to reality, only made bearable for the reader by the writer's talent. In the book, Moravia portrays a cross section of the empty, deceitful and miserable life of a Roman bourgeois family in decline. The family is composed of Mariagrazia, a shallow widow who inherited the large Villa Ardengo, in which the story is mostly set; and her two children, Carla and Michele, both in their 20s, who are unhappy and alienated, but unable to change their lives. The other characters are Leo Merumeci, Mariagrazia's lover, a wealthy, unscrupulous investor who has lent her money and plans to appropriate the family's villa; and Lisa, a divorcée who is Mariagrazia's friend, but also Leo's former lover. As the plot unfolds, Leo seduces Carla, and Lisa seduces Michele. Carla and Michele have a painful awareness that giving in to Leo and Lisa's propositions is morally wrong and against their true desires, but are unable to resist. In the end, Leo decides to marry Carla. As Borgese wrote, Moravia was merciless and unsparing in his depiction, and did nothing to embellish his 'decaying' subject matter, an approach which matched his unadorned style. His perspective was not one of 'perverse complicity' ('complicità perverse') or, on the contrary, of overblown moralism; rather, he cultivated a detached disgust that was all the more effective in highlighting the bleakness of the story and the moral decay of an entire social class.

This grim depiction of an amoral, hypocritical bourgeoisie fills the novel with ethical tension and foregrounds a desire for moral change, expressed mainly through the (unfulfilled) yearnings of the younger characters. While Mariagrazia, Leo and Lisa seem unaware of this and mostly at ease in their world, the general lack of transparency and moral principles distresses Carla and Michele, who feel alienated and desperately crave a new, different life. They long for a world in which behaviour, relationships and discussions 'adhere to reality', in which people are 
honest and act upon their feelings, rather than being governed by indifference and paralysis. However, this desire alone is not sufficient to give them the new way of life to which they aspire; they are powerless and ultimately find themselves stuck in their numb and unhappy livesCarla's obsession with a 'new life' even leads her to sleep with Leo and arguably leaves her worse off. While some post-war critics saw this ethical tension as a sign of the antifascist nature of the novel, many Fascist critics, on the contrary, hailed it as a banner of a new Fascist morality grounded in the need for honesty, transparency, and the value of action, which the new realist novel was expected to embody (see Ben-Ghiat 1995, 643-45; see also Talbot 2006, 129-30). ${ }^{5}$ The novel was understood by many critics as a condemnation of the apathy, hypocrisy, and amorality of the liberal bourgeoisie, which in their view was completely at odds with the Fascist moral code and would be swept away by the regime. Several exponents of Fascist culture, in particular those of the so-called 'sinistra fascista' (Fascist left wing), praised it as a 'significant manifestation of a "constructive" and "moral" literature, immersed in contemporary life' (Buchignani 2012, 68). The most illustrious of these critics was Giuseppe Bottai, who praised Gli indifferenti in the pages of Critica fascista (Bottai 1931, 1932; see also Ben-Ghiat 2001, 61). Certainly, as Moravia stated in his abovementioned 1927 article in La fiera letteraria, Gli indifferenti responded to the need for a reconnection of the novel with reality, in order to restore its crucial documentary and ethical-cognitive value, and thus fulfil a new ethical commitment that was expected from the modern writer (Voza 1982, 209). The novel was thus highly representative of the constructive and ethical spirit of this era.

\section{Luce fredda: The Morality of the Novel}

Umberto Barbaro was an eclectic and extremely dynamic figure in the twentieth-century Italian cultural and artistic landscape. He was a tireless innovator in different artistic fields (mainly literature, theatre and cinema) during the Fascist and post-war periods, and he frequently engaged in theoretical reflection on the arts. His 1927 article on expressionist playwright Ernst Toller offered a critique of the dominant literary 
approaches of Crocean philosophy, dannunzianesimo, ${ }^{6}$ and Futurism, highlighting their shared aesthetic principles in order to move beyond them (Barbaro 1927b). He identified these as a disengagement with content on the one hand, and stylistic fragmentism on the other. According to Barbaro, these artistic tendencies were not equal to the task of representing modern reality and fulfilling the role that art had to play in a modern, mass society. His artistic ideal, set out in a large number of writings, was opposed to the idealist tradition and upheld a close relationship between art and life, seen as crucial in allowing art first to exceed the individual dimension, and then act upon and transform reality. ${ }^{7}$ Clearly, the type of art that Barbaro envisioned had a profound political meaning and potential, which would be fully realized in the post-war period, through Barbaro's activity as a film critic and theorist of socialist Neorealism (see Brunetta 1976; Briganti 1984; Di Giovanna 1992, 185-91). Although Barbaro was a Communist, his anti-individualist, anti-Romantic, and socially oriented conception of art, as well as his revolutionary and 'populist' language, were perfectly compatible with the type of engaged aesthetics promoted by the regime and endorsed by Fascist intellectuals which, focusing on the construction of a new morality, was eagerly embraced by Barbaro (see Brunetta 1976, 21-22; Andreazza 2008, 324-25; Ben-Ghiat 2001, 63). In the late 1920s and early 1930s, then, revolutionary right-wing and left-wing writers worked together towards the construction of a new art, and specifically a new literature (Buchignani 2012, 68).

The affinities of Barbaro's artistic views with those upheld by the Fascist cultural 'programme' manifested themselves in the various connections and relationships he built with intellectual figures and groups openly endorsing the regime (Andreazza 2008, 322). His aesthetics overlapped significantly with the theories championed by the journal 900 (see Chap. 5), and indeed Barbaro, like Moravia, gravitated towards the Novecento movement, contributing several articles to this and other journals (see Buchignani 1987, 728). His aesthetic ideas fed into a distinct movement called Immaginismo, made up of a group of artists and writers (including Vinicio Paladini, Dino Terra, Bonaventura Grassi, Paolo Flores, Ivo Pannaggi, and others) which grew out of the Rome avant-garde scene of the late 1920s (see Carpi 1981a; Buchignani 1987). Barbaro, who 
proclaimed himself the 'theorist' of the movement, founded the journal $\mathrm{La}$ ruota dentata in February 1927, in order to provide the group with an artistic and theoretical platform. Due to a lack of funds, however, the journal was discontinued after the first issue. The journal, and the movement behind it, aimed to bring together all the avant-gardes, as the first page of the only issue of La ruota dentata reveals: 'Futurists, suprematists, cubists, expressionists, constructivists, avant-gardists, realists, everyone with the Immaginist movement!'. ${ }^{8}$ Elsewhere, Barbaro claimed that the aesthetic programme gathering the avant-gardes under the banner of the Immaginist movement was the only possible way forward, through 'a common way of seeing reality and trying to make this reality creative, and modify it through art' (Barbaro 1927c). ${ }^{9}$ He thus privileged the subversive and 'political' function of avant-garde art, rather than shared formal features, in this Immaginist attempt at rallying the avant-gardes (Andreazza 2008, 320).

Barbaro also upheld the idea of art as a means of shaping reality in his crucial article in La ruota dentata, 'Una nuova estetica per un'arte nuova', which occupied almost half of the journal's sole entire issue (Barbaro 1927a, reprinted in Barbaro 1976, 75-84). This article offers a critique of Croce's aesthetic theory, which was based on the process of intuitive expression, denying any relationship between art and reality and thus underpinning the bourgeois ideal of 'pure' art, which Barbaro rejected. He proposed an alternative model of the creative process comprising two moments: a 'destructive' one, governed by fantasy, and a 'constructive' one, governed by imagination. Through this two-phase process, the subject is taken out of the self to undergo change, before re-entering the self and restoring harmony (Barbaro 1976, 75). Barbaro saw this detachment of the subject from the self and its subsequent recomposition as constituting the heuristic essence and universal value of art, ensuring its relationship with life, as opposed to the sterile knowledge and expression of the self offered by Crocean aesthetics (Ibid., 78). He concluded that the empty formula 'art for art's sake' should be replaced by 'art for life's sake' ('arte per la vita') (Ibid., 84).

Barbaro discussed similar ideas, this time specifically in relation to the novel, in an article from 1932, the year following the publication of his novel Luce fredda, which, as will be shown below, constituted a key artistic 
actualization of his theoretical reflections. In this article, entitled 'Considerazioni sul romanzo' (Barbaro 1932, reprinted in 1976, 132-38), he reaffirmed the power of art to create reality and shape every other human activity, extolling its 'efficient morality' ('moralità efficiente') $(1976,133)$. The novel, in particular, was an artistic genre that tended to minimize the more lyrical and Romantic elements of art, constituting the archetypal form of the 'well-conceived and well-built artwork' (l'opera costruita e pensata') (Ibid., 135), to which artists felt the need to return, following not only the excesses of 'pure art' but also 'the over-indulgence with either pure technique or straightforward realism' (Billiani 2016, 490). For this reason, the novel had been disparaged by advocates of 'pure art', who feared the moment when art and life would be so close as to correspond completely, and 'pure' artworks would disappear (Barbaro 1976, 136).

Crucially, Barbaro stressed the artist's urgent moral duty to effect a renewal of reality and society through a renewal of art itself (Ibid., 137). This strong moral, and hence social function of the novel would be realized by shocking its readers' consciences and thus encouraging them to make their reality better, to transform their world, thereby turning art into a driving force of social change:

The real morality of art lies in reconnecting readers to, and forcing them into, the hardships of everyday life, to provoke their anxious desire to escape, to do better, to transform themselves and the world [...]. (Barbaro $1976,138)^{10}$

With this article (and others), Barbaro announced and clarified his contribution to the project of the renewal and 'reconstruction' of the novel, grounded in the principles of the return to realism and 'well-built' artworks, the morality of art, and the artist's relationship with the masses. His artistic and intellectual endeavours can thus be seen as a 'constructive' evolution of the avant-garde culture that had developed in the early decades of the twentieth century (Buchignani 2012, 67), dismissing the latter's obsession with technique, but preserving the ethical value of art. We will now discuss these principles, which formed the intersection of the literary and architectural fields, in relation to the novel Luce fredda. 
Luce fredda was published in 1931 and has significant points in common with Moravia's Gli indifferenti, beginning with a shared cultural milieu in terms both of its subject matter — the Roman bourgeoisie-and its origins in Roman avant-garde circles. Furthermore, the two novels share a fierce anti-bourgeois sentiment, ethical tension, the rejection of lyricism and fragmentism ('prosa d'arte') in favour of a well-built narrative, and realist aesthetics, albeit interpreted and applied in different ways (see Carpi 1981a, 141-45; Andreazza 2008, 325). However, the two books differ in other respects. Barbaro's realist intentions and social concerns coexist with a thoroughgoing narrative, stylistic, and linguistic experimentalism that differs from Moravia's more traditional narrative choices. Like Gli indifferenti, the book portrays some young members of the bourgeoisie who, like Carla and Michele Ardengo, are alienated by the hypocrisy and lack of value they perceive in their world. Similarly, the older, pre-Fascist generation (represented, for instance, by Maria's parents, father Roggi, and the lawyer Falerno) is at ease with the status quo, whereas the younger generation (represented by Sergio, Maria, Leone, Tilde, Lorenzo, and Vincenzo) is uncomfortable with bourgeois codes of conduct, and feels suffocated by the apathy and immobilism that dominate their world. However, they are generally too immersed in, and influenced by this culture, and the attitudes and behaviour it engenders, to be able to break free, embrace a new morality and change their lives.

Compared to Gli indifferenti, however, there are more positive examples of action and change. Maria decides to renounce her privileges and seek financial independence, so she leaves her parents' house and moves to Rome to look for a job (131-32). ${ }^{11}$ This happens shortly after she visits a factory owned by her father, and meets working women who are exploited and physically debilitated by their work, yet energetic and dignified (153-55). The youngest character, 17-year-old Ruggero, represents an even younger generation which has grown up under Fascism and is thus less influenced by bourgeois liberal norms and behaviour; this generation will go one step further and transform this realization into action. Indeed, Ruggero takes moral obligation to the extreme committing suicide to redeem himself for a misdeed (forging his father's signature in order to obtain a loan from the bank). Despite the tragic nature of this action, it is taken as an example of righteousness by other characters, in 
particular Sergio. He sees Ruggero's uncompromising behaviour as 'proof of the possibility of salvation on earth' and of the 'categorical existence of morals, independent of norms and external sanctions' (224). This gesture is a spur for him to 'throw himself into action' too, but he is immediately gripped by fear and insecurities which, once again, paralyse him, and he falls asleep. He is thus unable to effect the necessary change in his life, reminding us of Michele Ardengo's failed attempts to challenge events and behaviour he perceives as wrong.

In a 1933 article, tellingly entitled 'La mia fede' ('My faith'), Barbaro wrote that 'if we wanted to reduce it to its essence, my aesthetics would concern the relationship between art and life' (Barbaro 1933, reprinted in 1976, 139). ${ }^{12}$ For this reason, he advocated a 'demanding, problematic, and content-focused' type of production ('impegnativa, problematica e contenutistica') (Ibid.), marked by a constant ethical tension and a strong rejection of individualism. He claimed that this conception of art and life was strongly reflected in Luce fredda. The book indeed represents a complex specimen of a modern novel that thematically, but also narratively, rejects and defies individualism. Through his narrative choices, Barbaro distanced himself not only from the shallowness of prosa d'arte, but also from a naturalistic type of realism, based on a simplistic and outdated relationship between the subject and the object (Salaris 1990, 238; Billiani 2016, 490). Instead, Luce fredda could be defined as a 'polyphonic' or a 'choral' novel: although the character of Sergio is slightly more prominent than the others, it is difficult to identify a protagonist figure in the traditional sense of the term. The novel is rather about a group of people, representing the Roman petit-bourgeois intellectual or pseudo-intellectual class. The text is thus marked by an extensive, almost structural, use of free indirect speech and inner monologues. The narrative is not linear, but comes across rather as an assembly of narrative sections and fragments of 'reality' (like letters and excerpts of journal), reminiscent of the cinematographic technique of montage (Durante 2000, 125).

Luce fredda was thus an experimental model for Barbaro's new concept of Neorealism, departing from naturalism and rooted in the experiences of the avant-gardes, but progressing beyond the latter by embracing the need for the constructive engagement of literature and the arts in modern 
society. As he explained in a review of Sejfullina's novel Virineja, progressing beyond avant-gardism would mean that 'formal and technical values, whose sphere almost all modernists have limited themselves to, are [...] balanced with a rich and elevated content' (Barbaro 1928, reprinted in 1976, 88-89). ${ }^{13}$ The novel's choral perspective, giving voice to a multitude of characters whose subjectivities, through the use of free indirect speech, are mixed and almost melded into one another, ${ }^{14}$ can be related to the notion of the 'collective novel', which was popular under Fascism. For many critics and writers, this was the literary equivalent of Fascist collectivism, and a response to the need for an anti-individualistic art that would sublimate individual experiences into collective ones, making art modern and relevant for a mass society:

The attempt at reconciling, including in the artistic sphere, the individual with society, the singular with the multiple, finds a solution in a literature that adheres to reality and goes beyond the traditional, biographical and psychological novel, in order to become the narration of collective facts or the projection of individual facts onto the masses. The collective novel should thus be a social or choral novel. (Busoni 1934, cited in Buchignani $1987,740)^{15}$

The same concern was central to the field of architecture, as architects belonging to the Modern Movement in particular believed that the Fascist revolution would be expressed and brought about through buildings destined for the collectivity (see analysis of buildings in the second part of this chapter).

\section{The Romanzo Fiat and the Creation of Modern Myths: 522 and La strada e il volante}

The novels 522: Racconto di una giornata and La strada e il volante, written by Massimo Bontempelli and Pietro Maria Bardi, respectively, grew out of a unique partnership between literature and industry (specifically the Fiat company). As such, they exemplify the new modalities of the writing 'profession' ('mestiere'), in Bontempelli's definition, and the new place and function of writers in modern mass society, which Bontempelli had 
addressed in his theoretical reflections on modern artistic production (see Chap. 5, pp. 101-102). This partnership was the result of the initiative of Gino Pestelli, hired by Fiat in 1928 to direct their press office. Before that, Pestelli had been the co-director of the Turin newspaper La stampa (Tongiorgi 1994b, 399). Pestelli had revolutionized Fiat's advertising strategy, adapting it to the changing conditions of modern mass society, and to the new market that Fiat was seeking to create and expand. ${ }^{16}$ Fiat needed a different promotional approach to target potential buyers for the new range of popular, mass-market models which it was launching in this period. Pestelli developed an innovative promotional strategy, in which literature featured prominently. Fiat employees and workmen were encouraged to try their hand at writing, and their texts were published in the company magazine Il rosso e il nero, founded in 1932 to replace the more refined and elitist Rivista Fiat that had been discontinued in 1927 (Tongiorgi 1994b, 401). Pestelli also intended to get 'established' writers involved and start a programme of commissioned literary pieces, in order to raise the company's cultural and intellectual profile. In a programmatic document produced in 1929 to explain Fiat's new advertising strategy to Mussolini, he described his intention to 'create a veritable Fiat literature' ('creare una vera e propria letteratura Fiat'), comprising different genres: 'the Fiat novel, the Fiat short story, the Fiat tale, and so on' ('il romanzo Fiat, la novella Fiat, la storia Fiat, ecc.') (cited in Tongiorgi 1994b, 405, emphasis in original; see also Galateria 1997, 708). Pestelli's strategy was not limited to the production of alluring imagery around single products, but rather set out to create a veritable 'moral culture' associated with Fiat.

This is the background to the significant (and unique, in the context of interwar Italy) collaboration between Fiat and the established duo of Bontempelli and Bardi. Pestelli got his friend Bontempelli, who had a notorious passion for cars involved first. Bontempelli was commissioned a novel that would 'advertise' a Fiat model. The contract was signed in 1930 and the writer was remunerated with a Fiat 514, establishing a seemingly rather rudimentary relationship between artists and industrial patrons. A year later, he swapped the 514 for a 522, the car which was the protagonist of his novel, written in 1931 and published by Mondadori in 1932 with the title 522: racconto di una giornata (Bontempelli 1932a; see Galateria 1997, 708-10). It may have been Bontempelli who put forward Bardi, his 
friend and collaborator, as the next 'Fiat author'. Bardi wrote a novel on the following model, the Fiat 1500, which he published in 1936, with the title La strada e il volante. He was also paid in kind-with a Fiat 1500. Bontempelli and Bardi worked together on various cultural projects, mainly magazines, which developed the theoretical encounter between architecture and the novel. As shown in Chap. 5, the most important of these was Quadrante, which constituted the most significant platform for the identification and development of the theoretical-aesthetic principles that linked architecture and the novel. The fact that they were involved in the 'Fiat novel' writing programme is thus very significant, because it places this literary endeavour in the context of the aesthetico-political projects articulating the theoretical and aesthetic connection between the two artistic forms. Furthermore, Bardi's La strada e il volante was published by Edizioni Quadrante, a publishing initiative that emerged out of the magazine, making the link between the two experiences even stronger. As we argue below, the two short novels displayed and developed some of the principles that were shared by architecture and the novel as aestheticopolitical projects directed at the cultural and political modernization of Fascist Italy; namely, the anti-subjective and anonymous spirit, the creation of myths for the modern era, and the fulfilment of art's social function in modern mass society.

The establishment of a partnership between literature and industry provided a way of actualizing an idea of art that moves towards reality and finds a suitable role within mass society, a notion central to Bontempelli's thought. The attempt at producing an 'advertising' artwork enabled the artist, specifically the writer, to fit into the structures of modern society, giving rise to new modalities of the production and enjoyment of art. The modern writer was, according to Bontempelli's vision, a well-integrated, constructive and dynamic member of a society of which technological and industrial development was a constitutive part; no longer was he a subversive, alienated figure. In this paradigm of literature in modern society, writers were first and foremost creators of myths for the modern age. Through this mythopoeic process they were to perform their social function and establish a connection with the masses. As discussed in Chap. 5, in order to produce literature which possessed this social utility, writers needed to detach themselves from their subjectivity and 
build stories, create 'objects', in the same way as architects, achieving the ideal of anonymity. These stories would help readers make sense of reality-especially modern reality. There was no scope for the expression of the inner self that had been the prerogative of Romantic and early twentieth-century literature.

522 and La strada e il volante are emblematic examples of this idea of literature and of the role of the writer in modern society. 522, in particular, achieves the mythologization of modern reality through Bontempelli's favoured aesthetic mode, 'magical realism', which he considered the best aesthetic strategy for realizing this artistic ideal. It consisted in transforming everyday reality through literature by attributing new, unexpected, 'magical' elements to it, shaped by the writer's imagination. This aesthetic strategy allowed everyday reality to be turned into myth, creating stories that would be immediately comprehensible, engaging and foundational for the collectivity, thus fulfilling art's social function. This was achieved in 522 through the skilful anthropomorphization of the automobile, which becomes the novel's real protagonist. 522 is attributed both a physical and a psychological dimension that makes 'her' ('car' is feminine in Italian, and 522 is not only humanized, but also feminized) feel physical sensations and psychological emotions that challenge the image of the car as a cold and insensitive machine. The narration of anthropomorphized impressions and feelings is intensified by the idea of the freshness and purity of emotions experienced for the first time. Indeed, Bontempelli did not choose to narrate just any day in the life of 522, but rather her first 24 hours outside the factory-her first day of 'life'. This narrative choice affords the story a typically 'magical realist' perspective that comes across as new, primordial and unspoiled. 522 sees and perceives everything with a 'lucid wonder' that epitomizes the sentiment underlying the reconstruction of the world according to the principles of magical realism, and allows her-and the readers-to experience everyday reality as new and extraordinary (Galateria 1997, 714). The novel is infused with a sense of recreation and a new beginning that evokes the palingenetic spirit of the Fascist era. Bontempelli crafted a story that turned an ordinary episode into a magical adventure and a myth for the modern era, which would help readers familiarize themselves with an object that was still perceived with some hostility and/or awe by common people, but was destined to become a mass consumer product, and a symbol of modern society. 
The novel addresses the theme of the relationship between man and machine, and between nature and machine, representing it not in terms of conflict, but rather of cooperation and harmony. As previously mentioned, Bontempelli saw the writer, and himself, as a modern man, integrated in modern society and looking favourably rather than problematically, upon technological and industrial development as an inevitable and indisputable fact of the society of which he wanted to be a part. The writer was no longer an outcast, and his myths were a positive response to modernity, not in conflict with it. At the same time, both 522 and La strada e il volante are removed from the 'aesthetic mythologization of the machine' that was typical of early twentieth-century avant-gardes (Tongiorgi 1994b, 406). Instead, they aimed to promote the familiarization and popularization of the automobile as a consumer product and a reliable instrument of modern life, accessible to all—Bardi even included a list of twelve rules to be followed by car drivers in the novel's penultimate chapter. The two writers progressed beyond an ideal of speed as a risky pursuit carried out for its own sake and without any practical purpose. Their Fiat novels instead represent and exalt a 'controlled, reasonable, reassuring' idea of speed (Galateria 1997, 716), which frames the car in terms not of a formidable and dangerous technological object for the elites, but rather a new, loyal and dependable companion for common people in their everyday lives. This new 'tame' image of the automobile is expressed clearly in Bontempelli's preface to Bardi's La strada e il volante, which establishes a clear continuity between the two books:

We are a long way, here, from the emphatic discovery of speed to which past literature-from Carducci's beautiful and horrible monster to the prewar speed-centred avant-gardes-accustomed us. Here you do not even feel speed anymore: this is the aesthetic, intimate and truly important discovery of Filiberto's simple adventures. [...] This is how the rhetorical absurdity of speed as an absolute fact is dismantled. (Bontempelli 1936, 8) ${ }^{17}$

This shift in the representation and mythologization of the car is part of the writers' effort to popularize their literary products and connect with the masses, which coincided with Fiat's advertising purposes in commissioning these novels. These were directed at changing the perception of the automobile in order to reach new categories of consumers for the new 
'low-cost' models and expand their market base. In this paradigm of art for the modern mass society, technology and machines had to find their place in the life of the everyday man, and thus needed to be humanized and made familiar.

As seen in Chap. 5, Bardi was not primarily a writer, but a critic of art and architecture, and the high priest of rationalist architecture. His trying his hand at writing a novel in itself constitutes a concrete encounter between architecture and literature. In his preface to La strada e il volante, Bontempelli commented upon and elucidated this encounter by stating that movement was the origin, and a constitutive part, of the new rationalist city:

all the movement found in new architecture sprang from the fact that the city started being seen not as a series of still contemplations [...], but as the product of the movement that men carry out in its streets. (Bontempelli $1936,7)^{18}$

Driving an automobile, he argued, was the most 'characteristic' of these forms of urban movement. The car, he continued, contributed with its rectilinear trajectories to modern 'smooth-walled' urban aesthetics. This explained how Bardi, the 'missionary' of rationalist (or rather 'natural') architecture, as Bontempelli called him ('missionario dell'architettura "naturale"'), had embarked upon writing a novel centred on Filiberto, a novice driver. Bontempelli's preface established a connection between literature and architecture through the myth of the automobile, which also, crucially, comes to embody Fascist morals here. Conveying a more radical and 'revolutionary' message compared to Bontempelli's 522, La strada e il volante narrates Filiberto's journey through Italy, from Rome to Turin, which functions as an anti-bourgeois path to personal growth (Tongiorgi $1994 \mathrm{a}, 22$ ). It thus shares 522's emphasis on a new beginning, the joy of discovery, and a fresh, unspoiled perspective on reality, as Filiberto is a 'neophyte', whose decision to embrace motoring changes his life. However, the new beginning here assumes a less 'magical' and more explicitly political meaning, as becoming a motorist is the means for Filiberto to achieve a personal transformation that turns him into the perfect Fascist: anti-bourgeois, collectivist, disdainful of risk and of any 
form of immobilism. Here, then, technological progress is not only framed as an aspect of the grandiloquent but undefined Fascist morality, but also Fascist ideology is effectively translated into the myth of the automobile, through Filiberto's unfolding psychological development. In this image of a new beginning can be discerned the primordial and palingenetic spirit that marked the Fascist era in all areas of public and private life, and the novel functions as an emblematic representation on an individual level of the anthropological revolution that the regime aimed to impose on the Italian population.

Filiberto is a lawyer-a bourgeois professional par excellence. What prompts him to seek a change is his self-perception as insecure, overcautious, boring, and afraid to take risks - in sum, the prototypical bourgeois that 'revolutionary' Fascists like Bardi so despised. In the change that leads him to embrace motoring, Filiberto 'went from the consideration of his own laziness to the consideration of the renewed life that surrounded him' (15). ${ }^{19}$ Here, Bardi celebrates aspects of the social life promoted by the regime. Not by chance, the list begins with a novelty that was a mainstay of Fascist architecture and of the rationalist movement, the construction of stadia, evoking the contribution of modernist architects to the new life created by the regime for Italians. He then exalts sport, dopolavoro ('after-work activities'), and the value of these practices in establishing a collective life. Speed as an ideal embodied by the car (provided that it is a 'reasonable' and 'functional' speed) is opposed to bourgeois immobilism, and represents the essential virtues of the Fascist man: dynamism, promptness, spontaneity, vigour, and bravery. Through the experience of movement and speed granted by the automobile, Filiberto undergoes a mental and psychological transformation that typifies the Fascist anthropological revolution:

With the new joy of the automobile, he reviewed his mental positions. He had got it into his head that behind the wheel, alone, speeding along the roads, conquering distances and freedom of movement, he would be able to think [...]. $(26)^{20}$

He develops an anti-democratic attitude, prone to action, functional to the streamlining and fast-tracking of mental and practical processes: 
Filiberto no longer reasoned like he used to, following the judicious principle of respecting the ideas and interests of the majority [...]. His reasoning had become streamlined; it moved forward, terse, swift and conclusive. The wheel gave him a new personality compared to other people. $(36)^{21}$

The novel also depicts wider transformations in the life of Italians, moving towards a motorized modernity which is similarly connected to the Fascist regime. For instance, Filiberto exalts the physical transformation of the peninsula, which the Fascists are covering with roads (Bardi $1936,40,95)$ and describes the increase in the Italians' use of cars, which provides new ways of spending free time, such as going out for short Sunday trips in the car (95). Among the most significant themes of the book is the celebration of Fascist corporativism and of the collectivist spirit it generates as an essential part of Fascist ideology and the anthropological revolution, and of the social cohesion it has created. The most remarkable section of the novel in this respect is the chapter depicting work in a factory (Chap. 9, 79-86), in which technological industrial production is portrayed as a collective process, which erases the individuality of single workers and class differences in the interest of the collectivity (Tongiorgi 1994a, 28-29). Filiberto would like to know who is the engineer who designed the car that is being assembled before his eyes, but nobody can tell him: '[...] it was all the engineers, it was all the technicians, it was all the workers sharing ideas, work discipline, and an everyday aspiration to achieve the best result [...]' (86). ${ }^{22}$ Clearly, this section also functions as a celebration of Fiat and of the supportive and collegial work environment it promoted, contributing to the new Fiat promotional programme's objective of creating a 'Fiat morality', and strongly connecting it with Fascist ethics.

\section{The Symbolic Function of Architecture in Luce fredda, La strada e il volante, and Gli indifferenti}

The close connections and intersections between architecture and the novel that existed during the Fascist period are also manifested explicitly in the content of the novels. Most of the works analysed feature architecture, and reflections on architecture, as an important presence, generally 
with a central symbolic function. This reflects the well-established presence of architecture in the intellectual and artistic horizon of these novelists.

Luce fredda opens with Sergio, the pseudo-protagonist, looking for a new accommodation - the theme of the house, as in Gli indifferenti, is from the very beginning given prominence and placed in a hyper-central position in the narrative construction. Even more remarkably, Sergio's indignant reflections on houses and living spaces, which follow the visit of the first room he is considering, are an almost too precise and rigorous presentation of rationalist polemic against 'old' architecture, and of the main principles of the programme through which the rationalist movement was fighting its cultural battle. Sergio complains about the small and overcrowded spaces in which most people live-including himselfas he believes that the quality of the environment in which one lives influences one's ideas, behaviours and morality:

Absurd shambles, overloaded with spoilt furnishings and useless, tacky baubles ... What kind of ideas can develop in similar environments, what kind of souls can be formed? The house should be made entirely of concrete, glass, porcelain-clear, clean, transparent, so as to provoke in those who live in it the love for order, organisation, swiftness, determination, balance; all the indispensable requisites for a dignified life. (Barbaro 1990 [1931], 9) $)^{23}$

In his tirade, which for its contents and its caustic language could be an article in Quadrante, Sergio even mentions the new construction materials, which for their simplicity, lightness and functionality had been enthusiastically adopted by modernist architects, in particular concrete and glass (see the section on the Fabbrica Olivetti below). Sergio then goes on to uphold some of the cornerstones of the modernist architectural revolution: the rejection of the 'artistic' element of architecture, modular buildings, standardization, and Taylorization, which in Italy had been theorized and championed by the likes of Giuseppe Pagano, Alberto Sartoris, Adriano Olivetti, Luigi Figini, Gino Pollini, Enrico Griffini, and others. ${ }^{24}$ Finally, he reiterates that architecture is a 'social art' because it has an impact on society, people's life and social behaviours: 
Build in series and to hell with art! Standardize, Taylorize ... Smash the pots, the knick-knacks, the paintings and all the rest ... Or at least scrape these dusty, damned hovels to the bone, so that they are not repulsive from the outside, and that inside one can work, rest, be content, and conceive the idea of a healthier, cleaner future!

It really is true that architecture is a social art! ... But go say that to those charlatan architects! (Ibid.) ${ }^{25}$

Architecture and the remaking of houses and living spaces is cast as a fundamental part of the 'moral change' that Sergio and other characters of Luce fredda dream of, but cannot achieve. Indeed, Sergio's outraged reflections about architecture, and about his accommodation, are thwarted by self-doubt and apathy, and ultimately come to nothing, like all other instances in which he desires change:

But the heat and the animosity betrayed his own convictions, distorting them. In the end, Sergio smiled at his usual outburst. At the end of the day, you adapt yourself [...] and this is the most hideous thing. You end up adapting yourself, and this intolerance is temporary, fleeting. (Ibid., 10) ${ }^{26}$

Unlike Sergio, Filiberto, the protagonist of Bardi's Fiat novel La strada e il volante, has acted upon his dissatisfaction and transformed his life, thanks to the radical change brought about by his adoption of motoring as a lifestyle and almost a 'religion'. In a symbolic moment of this transformation, when he is preparing for his life-changing driving trip to Turin, and has started behaving according to the impulses of his new self, he suddenly decides that upon his return he is going to get rid of what he now perceives as obsolete and stifling furnishing in his office:

Upon his return from his trip, he would change his office: he would jettison the 16th century-style furniture, tear up the curtains, sweep away the neoclassical inkpot. Away with the smell of mould, staleness, and bureaucracy. (Bardi 1936, 34) ${ }^{27}$

Old-fashioned furniture represents Filiberto's former bourgeois self, which he has disowned. The renovation of his working space is thus a 
consequence of the moral change that has invested his life- - he is not a boring, insecure, shy lawyer anymore, and feels uncomfortable in a working space that does not reflect his new identity. In the case of La strada e il volante, the inclusion of an, albeit brief, allusion to architectural and design innovation as an element of the formation of a Fascist, antibourgeois identity is even less surprising. As we have seen, Bardi, despite not being an architect, was a staunch supporter of the rationalist movement and the spearhead of their cultural battle.

Finally, the theme of the house, and therefore indirectly that of architecture, is central to Moravia's Gli indifferenti. The entire narrative revolves around Villa Ardengo, which is also where a large part of the action is set. As Esposito has argued, 'Gli Indifferenti is nothing but the story of the house and of the bundle of conflicting relationships that its possession [...] provokes in the protagonists' (Esposito 1978, 9). The house and its ownership are the main prerogative and the emblem of that amoral and corrupted bourgeoisie, which is the subject of the novel and the target of the book's condemnation. According to Voza, it is in the house, and in the relationship the characters establish with it, that the evil of indifference is outlined. Villa Ardengo, its rooms and its objects 'become emblematic of a bourgeois universe, deprived of values and inhabited by an elementary and paralysing logic of inauthenticity' (Voza 2007, 152). The connection between decadent, outdated architectural forms and the amorality and irreversible crisis of the bourgeoisie is more explicit in one of the short stories which Moravia published before Gli indifferenti, 'Villa Mercedes'. Its relevance to the novel itself is that, as has been established by scholars, it constitutes an antecedent, or even 'preparatory work', for Gli indifferenti (the expression has been used by Carpi [1981b, 699]). The short story concerns a neighbourhood of recent construction, whose houses are described, towards the end, as 'the secret villas of the false architectures' ('le ville segrete dalle false architetture)' (reprinted in Carpi $1981 b, 705)$. Despite the 'modern comforts' with which all houses are equipped, it is evident from the language, the images and the metaphors used to describe the neighbourhood that we are worlds apart, here, from the rationalist model and its connotations: Villa Mercedes, and the neighbourhood, are associated with death, disease, decadence, 
social and cultural crisis, and especially falsehood, inauthenticity and artificiality. It is worth mentioning that Interplanetario, the journal in which the short story was published, was an early advocate of rationalist architecture, and championed it specifically as an anti-bourgeois endeavour (Carpi 1981b, 700).

\section{Conclusion}

The novels analysed in this chapter are illustrative of various aspects of the synergies between architecture and the novel as intersecting aesthetico-political endeavours, and in different ways worked towards the construction of an 'arte di stato' envisaged by the regime. Gli indifferenti is a significant example of new realism and represents a crucial step in the reconstruction of the novel form, through the rationalization of style and the ethical tension that runs through the novel. Luce fredda also exemplifies the advent of a new realism that incorporates the achievements of the avant-gardes, but is grounded in a powerful engagement with the real and the construction of a new morality, as well as the anti-individualism and the collectivist ambition that marked both the novel and architecture. 522 and La strada e il volante embody a new conception of literature as a productive activity integrated within the structures of modern society and supporting its development. They illustrate the social function of literature as a means of creating myths for the modern world and at the same time building a Fascist morality. Besides examining these works in the light of theoretical and structural principles they share with architecture and coeval projects in the architectural field, we have analysed intersections between architecture and the novel as they manifest in the contents of most of the novels in question, in the importance and the symbolic function attributed to architecture in the texts. Architecture, houses, offices and their design are emblematic of the morality of characters and even of entire social classes or milieus, and form an integral part of their moral change, or lack thereof. 


\section{Architecture}

During the Fascist period, the Italian rationalist movement placed particular emphasis on the development of modern building types and forms, broadly falling under the categories of infrastructural and industrial architecture, supported by advances in construction technology and modern materials. ${ }^{28}$ While these 'utilitarian' and 'ordinary' building types had traditionally been shunned by architects in favour of more prestigious commissions, but they fully embodied the principles and values of the rationalist architectural 'revolution': the social function that constituted architecture's moral dimension, an anti-rhetorical and antibourgeois spirit, modernity, anonymity, functionalism, and aesthetic rationality. Rationalist architects and supporters of rationalist architecture rejected the idea that there was a hierarchy of building types (see, e.g. Piacentini 1928). In his article 'Larchitettura come morale e come politica', Bontempelli dismissed and subverted the disdainful 'division of labour' practised by 'conservative' architects, who wanted to keep for themselves the design of 'manor houses and villas' ('le case padronali, le ville'), and leave to young (modernist) architects those 'utilitarian buildings' ('edifici utilitari') which they disregarded as 'ephemeral architecture' ('architettura effimera'), 'things for engineers and not for architects' ('cose non da architetti ma da ingegneri'). The constructions that traditionalists disdainfully called 'utilitarian' were in fact, Bontempelli argued, 'representative, or rather "expressive", constructions par excellence' ("le costruzioni rappresentative, anzi "espressive" per eccellenza'), and had the noblest function, as they were destined for the collectivity (Bontempelli 1933d, reprinted in 1974 [1938], 335; see also De Seta 1998, 165).

In an article in Casabella, Pagano stated that the profile of a city and ultimately of a nation is not shaped by 'exceptional' works of architecture ('opere di eccezione'), but rather by what critics and historians would call 'minor architecture' ('architettura minore'): buildings for everyday use, without any pretensions to monumentality, and subject to functional and financial limitations (Pagano 1935, reprinted in 2008 [1976], 32). This 'modest and solid' architecture ('architettura modesta e soda') constituted the 'standard' production and embodied the principles of modern archi- 
tecture. Pagano echoed contemporaneous theorizations of the novel when he stated that 'the closer Italian architecture moves towards the people, the more national it will be' (Ibid., 35), ${ }^{29}$ and identified the fundamental principles of modern architecture as brutal clarity, exemplary simplicity and modesty, all of which were shared by projects to rejuvenate the novel. These 'ethical principles' ('principi etici') on which Fascist architecture and literature needed to be based, were ideally a reflection of Fascist values, namely '[...] those moral concepts which make of the new corporativist Italy a nation of soldiers who do not like the softness of luxury, nor the flattery of adulations' (Ibid., 35). ${ }^{30}$ As Bardi had claimed in his key contributions Architettura arte di stato and Rapporto sull'architettura (per Mussolini), the Fascist style was not merely an aesthetic matter; it was the '[...] use of a language as the expression of precise political content' ('[...] uso di un linguaggio come espressione di un derminato contenuto politico') (Ciucci 2002, 110). Works of architecture, and also of literature, would thus be judged in relation to their effectiveness in embodying Fascist values. Following this principle, Fascist architecture had to be 'serene and lively, sober and even martial, mirroring the qualities of strength and order that are favoured by the Italians of Mussolini' (Bardi 1931b, reprinted in Patetta 1972, 187). ${ }^{31}$

Pagano, Bontempelli, Bardi, and others were thus convinced that infrastructure, industrial architecture and public buildings were crucial to the development of Fascist architecture (see Chap. 5, pp. 111-112). It was through these works that the social modernization of the country would be brought about, realizing one of the primary goals of the Fascist regime (see Ghirardo 67-68). Many of these architectural forms were also seen by rationalist architects and Fascist officials as a means of configuring public space for collective use, to enable the inclusion of the masses in the life of the State, and their regimentation. They were therefore instrumental not only in the process of social modernization, but also in the fascistization of the masses, and the accomplishment of the anthropological revolution. These new building types are thus particularly representative of an understanding of architecture as a constructive, social, modernizing endeavour, a collective enterprise meant for the collectivity, which in the 1920s and especially in the 1930s converged with literary projects of 'reconstructing' the novel, based on identical principles. 
As we saw in Chap. 5, in 1933 Bontempelli praised the efforts of architects and writers, who had set an example for the other arts in embracing these principles, undertaking the creation of 'spacious constructions for the collective life of simple souls' ('ariose costruzioni per la vita collettiva degli animi semplici') (1974 [1938], 336). We will therefore analyse some significant examples of these building types, identifying the principles that connect them to the contemporaneous works that we have singled out in the field of literature. These are Santa Maria Novella railway station in Florence, a symbol of social modernization coupled with architectural modernity, and the extension to the Olivetti factory in Ivrea, which involved the rationalization and modernization of a crucial collective space, as well as the 'morality' of architecture. We will conclude the chapter, and our book, with the examination of the Danteum project, which constituted an ideal encounter between architecture and literature in a public building meant for the creation of powerful myths rooted in the national artistic tradition.

\section{Florence Railway Station: Social Modernization and Architectural Modernity}

Florence railway station, built between 1933 and 1935, is one of the most significant and iconic achievements of the Italian Rationalist movement, and epitomizes architectural modernity in a building which was in turn a symbol of the modernizing mission of Fascism. The 'problem' of the railway station in Florence arose in the context of a development programme for the city launched by Alessandro Pavolini, secretary of the Florentine PNF (Fascist National Party) between 1926 and 1934, aiming to enhance the network of transport links and other infrastructure in order to facilitate trade and access to the city (Conforti et al. $2016,11)$. However, it was also part of a broader national programme of modernization of the railway network-including the introduction of electrification-implemented by the Fascist regime (see Giuntini 2003), which demanded a corresponding modernization of railway architecture. Infrastructure, as already noted, constituted social and modernizing architecture par excellence. Railways, in particular, were the primary 
collective system of transport, and the regime therefore invested heavily in them. They represented the possibility of mobility and the promise of modernity made by the regime to all Italians, including the lower classes (see Ghirardo 2013, 67-68). The most prolific architect and engineer of railway stations under Fascism was Angiolo Mazzoni, an employee at for the Ministry of Communications. As such, he designed projects for the station in Florence, but after a heated debate, they were discarded owing to their 'ambiguous' style: not modern enough, but not really traditional either (Conforti et al. 2016, 13; Mariani 1989, 212). ${ }^{32}$ The design by the Gruppo Toscano, led by Giovanni Michelucci, was favoured. The group constituted the Tuscan regional unit of the MIAR (Movimento italiano per l'architettura razionale), and had been formed during the third national exhibition of rationalist architecture, organized by Michelucci himself in Florence, in March 1932. The group included Italo Gamberini, a final-year student at Florence school of architecture, who had been working for a year on a thesis developing a new design for the railway station (Etlin 1991, 308) (Fig. 7.1).

The construction of Florence railway station, and the polemic surrounding it, was one of the key moments of the architectural debate and

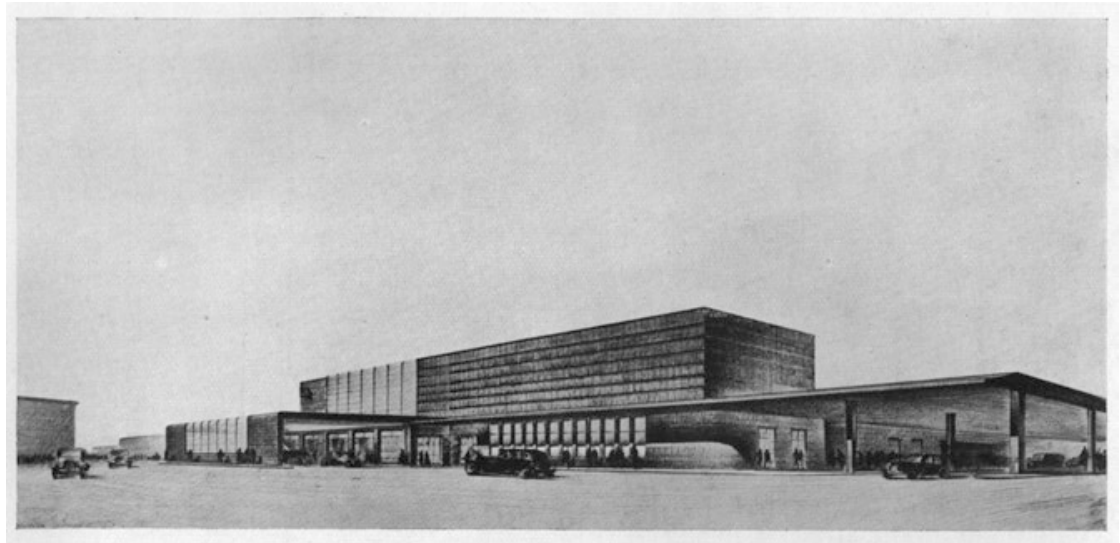

Progetto Michelucci-Baroni-Berardi-Gamberini-Guarnieri Lusanna. - I' Premio, - Veduta dall'angolo di Via Nazionale.

Fig. 7.1 Drawing of Florence railway station, Gruppo Toscano project. Architettura 13, no. 4 (April), 1933: 201 
the wider struggles for hegemony between antagonistic movements in Fascist Italy (see Chap. 4). It marked the peak of the rationalist front's success, as Pagano's article 'Mussolini salva l'architettura italiana', published in June 1934, demonstrates. Pagano triumphantly declared: 'Now modern architecture is arte di Stato' ('Ora l'architettura moderna è arte di stato') (Pagano 1934, reprinted in 2008 [1976], 9). The project had initially been given to Angiolo Mazzoni, but his proposal was the object of heavy criticism from various quarters; not just the modernist front, with Bardi of course leading the attack, but several journalists, artists and critics, and ultimately 'large sections of Italian culture' (De Seta 1998, 165). ${ }^{33}$ The polemics started with two letters from sculptor Romano Romanelli (who was not known for his modernist leanings), published on the newspaper La Nazione in 1932. In these, Romanelli questioned the validity of Mazzoni's project, arguing that the railway station of a city like Florence, rich in history and artworks, should not be monumental but on the contrary, functional and self-effacing, like a lift in a beautiful palace (Romanelli 1932a, 1932b; see also Etlin 1991, 308). The controversy developed and intensified in 1932 and 1933. As a result Costanzo Ciano, the director of the Ministry of Communications, decided to announce a public competition on 28 July 1932, despite personally approving of Mazzoni's project (Giacomelli 2003, 158, 164). The judging committee consisted of architects Cesare Bazzani, Armando Brasini, and Marcello Piacentini, sculptor Romano Romanelli, art critic Ugo Ojetti, and Futurist artist Filippo Tommaso Marinetti. The argument continued to rage and the debate over the station's construction received unprecedented public coverage, becoming the object of popular interest on a local and later a national level (Mariani 1989, 215; De Seta 1998, 165). On 12 March 1933 an exhibition was opened at the Palazzo Vecchio, in Florence, displaying the 102 projects submitted for the competition. In just one day, 40,000 people visited the exhibition, a truly extraordinary number (Mariani 1989, 217) (Fig. 7.2).

Despite his well-known conservative positions, Piacentini opportunistically lent his support to the modernist front in the competition, thus isolating Ojetti, and determining its outcome. He thereby implemented what Mariani has called the 'subtle strategy' of discarding his reputation as a conservative academic, instead legitimizing himself as a champion of 


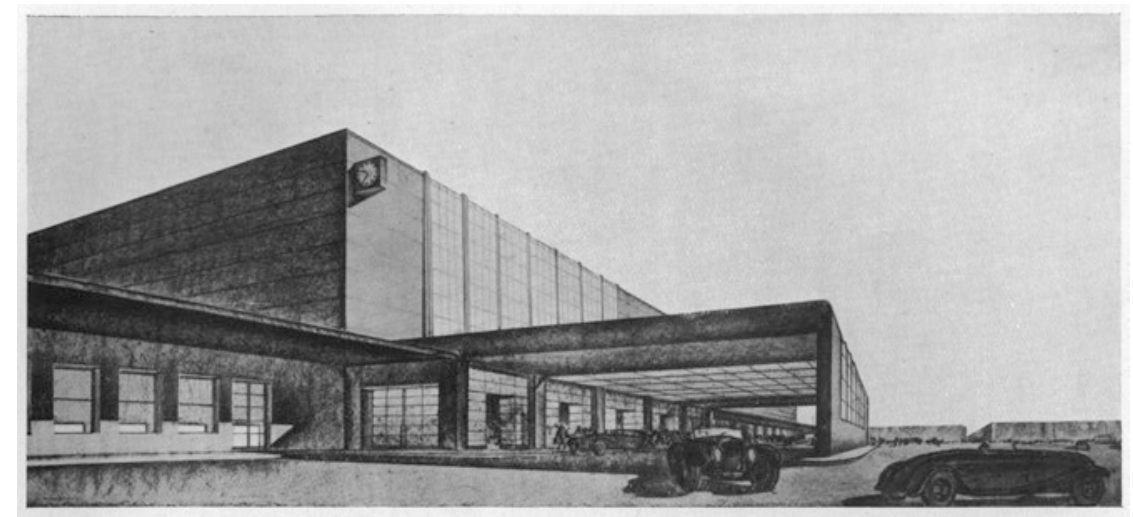

Progetto del. Gruppo Toscano. - Veduta da Via Leigl Alamanni.

Fig. 7.2 Drawing of Florence railway station, Gruppo Toscano project. Architettura 13, no. 4 (April), 1933: 203

modernity, and rising to a position of 'ideological, academic and professional control over Italian architecture' (Conforti et al. 2016, 14). In so doing, he also gained power over Bardi, who had until then been his staunch opponent, and the leading champion of modern architecture (Mariani 1989, 218-19; De Seta 165). It was Mussolini himself, however, who gave the Gruppo Toscano's project his seal of approval, after seeing the models of the station (see Pagano 1934, reprinted in 2008 [1976], 9). The Duce received the architects at the Palazzo Venezia and pronounced a famous speech in defence of modern architecture:

I wish to unequivocally clarify that I am in favour of modern Architecture [...] It would be absurd to not want a rational and functional architecture for our time. Every epoch has produced its own functional architecture. ${ }^{34}$

As well as stating that the Florence railway station was 'very beautiful' ('la stazione di Firenze è bellissima'), Mussolini upheld functionalist principles when he said that 'a station is a station and cannot be anything but a station' ('la stazione è una stazione e altro non può essere che una stazione'), and that 'not everything has to be monumental' ('non tutto deve essere monumentale'). He conveyed the idea that Fascist architecture had 
to be modern, clearly distinct from styles of the past, and that the style and form of buildings should reflect their function. Despite this endorsement, he would soon change his tune and increasingly favour monumentalist architecture (see Chap. 4).

The leading supporters of the rationalist front participated in the debate, almost unanimously praising the Gruppo Toscano's project for its modernity and for applying the precepts of rationalist architecture. In 1933, Bardi devoted considerable space to the discussion in his column in the journal L'Ambrosiano, also including contributions from other commentators. ${ }^{35}$ On 29 July he published a letter from the painter and theorist of abstract art Carlo Belli, one of the most tenacious opponents of Mazzoni's project, in which he asserted that young Fascist architects wanted an 'asbolutely rationalist' station ('assolutamente razionalista') (cited in Mariani 1989, 213, emphasis in original). He argued that rational architecture synthetized the spirit of the Fascist era, because like Fascism, it was 'courageously bare, genuine, and practical' ('coraggiosamente nuda, schietta e pratica') (Ibid.). He later praised the winning project, indicating that he saw these qualities in it. Bontempelli defended the Gruppo Toscano's design in various articles (reprinted in Bontempelli 1974 [1938], 322-27), locating the main principle of modern architecture, exemplified by the new station, in functionalism and a close connection with engineering, involving the 'construction of simple relationships and the pursuit of a plain naturalness' (' $[. .$.$] la costruzione$ di rapporti semplici e la ricerca di una piana naturalezza') (Ibid., 326). Pagano also weighed into the polemic in the pages of Casabella, the journal he had directed since 1933, and strongly supported the project of the Gruppo Toscano, despite having submitted his own project for the competition (De Seta 2008, lvi). In the aforementioned article Mussolini salva l'architettura italiana, Pagano saluted the new station as an avant-garde work, and the decision of the committee as a brave and responsible choice for which Italian architects had long been waiting (Pagano 2008 [1976], 136). However, the project's extreme linearity and rationality was also referred to by its detractors. Ardengo Soffici, for instance, argued that the Gruppo Toscano had not designed a station, but its 'packing crate' (cited in Mariani 1989, 217) (Fig. 7.3). 


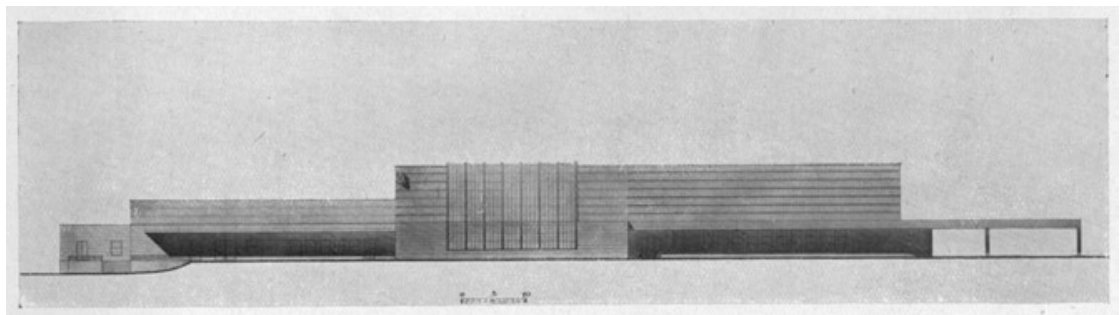

(Sopra) Prospetro sulla Plazza S. Maria Novella - (Sotto) Detraclio del prospetro.

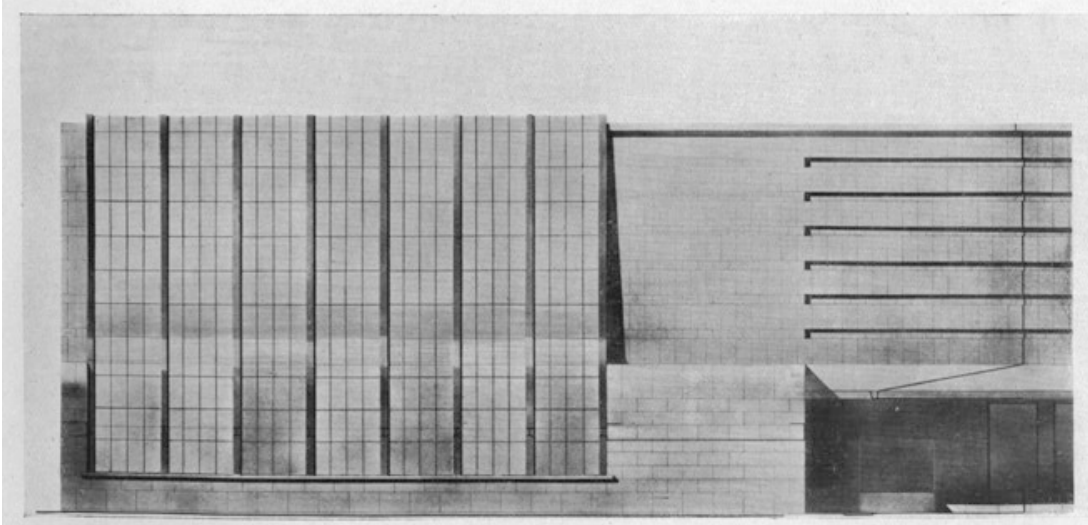

Fig. 7.3 Drawing of Florence railway station (with detail), Gruppo Toscano project. Architettura 13, no. 4 (April), 1933: 203

The building presents a low horizontal mass, bare and compact. It was conceived as a modern equivalent of Florence's city walls, which Michelucci had celebrated less than a year earlier for their simple, pure surfaces (Etlin 1991, 310). In both design and materials-it employs unpolished pietra forte, the typical stone used for Florentine civil architecture since the Middle Ages - the new station harmonized with its context, despite its undisputable modernity. Michelucci also explained in a letter that the building created a balance of masses in the square, because through its horizontal movement it emphasized the vertical movement of the adjacent church of Santa Maria Novella (Conforti et al. 2016, 26). The only element that interrupts the uniformity of the façade is the glass window composed of seven sections, the so-called waterfall of glass, which 'flows' over the building from one side to the other. The glass win- 
dow marks the entrance to the station and lights the large foyer containing the ticket office. The façade is free of any decorative elements, exemplifying the rationalist tenets of functional aesthetics. Three monumental fasci littori, emblem of the regime, placed on the Eastern corner of the façade and removed after the fall of the regime were the only exceptions to this rule. Inside, the building is also marked by an antimonumental and anti-rhetorical style, visible, for instance, in the elegant lettering of the signs indicating the different parts of the station. The space inside the station was rationalized and designed to cater for travellers' different needs, including facilities such as a left-luggage office, several waiting rooms, a restaurant, a bar and also a 'daytime underground hotel', which was later dismantled, featuring facilities for 'passengers' rest and hygiene' (Conforti et al. 2016, 20). The station was also, like so many Fascist public buildings enriched with artworks, realizing the Fascist ideal of the constant involvement and education of citizens through the enjoyment of art. Two panels painted by Ottone Rosai, depicting Tuscan landscapes, were placed in the bar. Another artwork by Fortunato Depero was to decorate the restaurant, but was never installed (Ibid.) (Fig. 7.4).

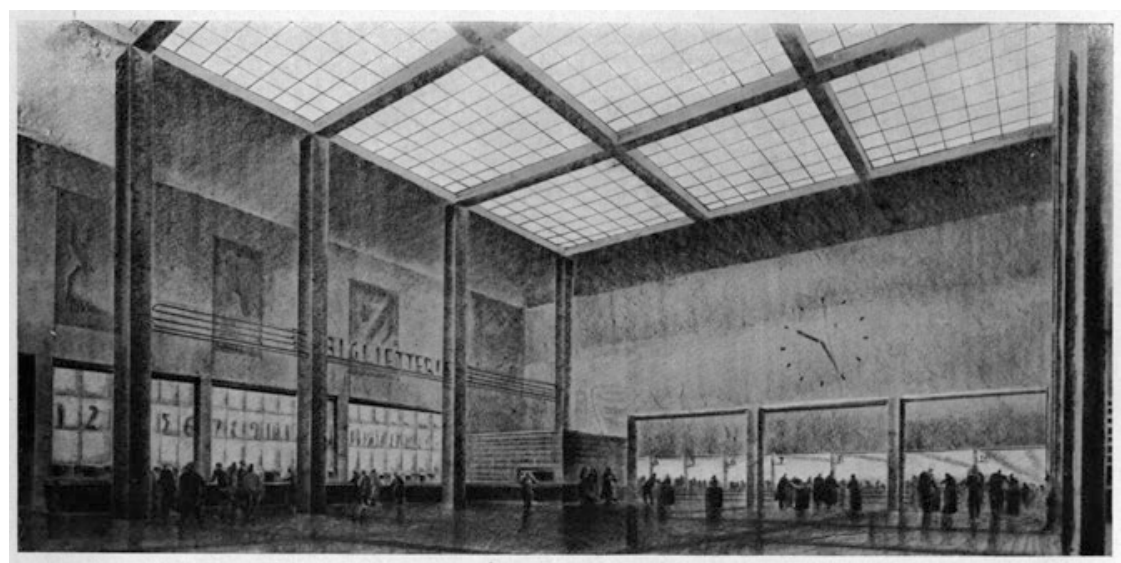

VEDUTA INTERNA DELL'ATRIo PAKTENZE.

Fig. 7.4 Drawing of Florence railway station (foyer), Gruppo Toscano project. Architettura 13, no. 4 (April), 1933: 205 
As an exemplary functionalist building, the station's linear and rational form mirrored its function, and reflected the shift in meanings and dominant perceptions associated with the idea of travel. The grand, monumental model of railway architecture that prevailed in the 19th and early twentieth century - exemplified by New York's Grand Central Terminal, but also by Milan's central station, which had attracted much criticismcorresponded to an idea of travelling as something exceptional and glorious. The qualities of plainness and constructive rationality which distinguished the new Florentine station, by contrast, embodied modernity in that they suggested a more humble, trivial, everyday idea of travel that was emerging in the 1920s and 1930s, and which the regime certainly encouraged (Conforti et al. 2016, 12). This process clearly mirrored the popularization and domestication of the image of the car pursued through the Fiat novels (see previous section). Yet this rationalization of architectural style also paralleled the rationalization and simplification of language and narrative construction in the novels analysed in the previous section, in particular Gli indifferenti. Being the result of a collective project, Florence railway station also embodied the rationalist ideal of the anonymous and collective nature of cultural production, which also marked the attempts, both theoretical and practical, to reconstruct the novel in the same period, as discussed in the previous section on novels, and in Chap. 5. Indeed, Bontempelli had explicitly argued that novelists should take inspiration from architects in order to achieve anonymity in their works and escape the influence of subjectivity in the process of artistic creation. This artistic quality was fully expressed in collective artworks, in which the co-authors necessarily had to renounce their individualism in favour of the pursuit of collective construction. Collective artistic production and anonymity also embraced Fascist antiindividualist and collectivist totalitarian rhetoric, and translated it into artistic production. This rhetoric was a cornerstone of the Gruppo 7 Manifesto (Rifkind 2012, 24), and of theorizations of modern architecture and the new novel more generally (see Chap. 5). As the writer Alberto Savinio, brother of painter Giorgio De Chirico, wrote ten years later, Florence railway station was anonymous and invisible, which allowed it to blend in perfectly with its surroundings. Echoing Romanelli's call for a discreet and unobtrusive station, Savinio argued that 'the most beautiful 
ornament of utilitarian buildings is discretion' (il più bell'ornamento degli edifici utilitari è la discrezione') (Savinio 1984 [1944], 352; translation by Etlin, 310). Anonymity was thus a key concept, both in the sense of anti-subjectivism, chiefly achieved through collective creation, and anti-monumentalism: a building, particularly if it is 'utilitarian', should not be conspicuous.

\section{The Extension to the Olivetti Factory in Ivrea: The Morality of Industrial Architecture}

These principles of anonymity and collective production can be identified in another project from the same period, the extension to the Olivetti factory in Ivrea, which patron of modern architecture Adriano Olivetti commissioned from architects Luigi Figini and Gino Pollini in 1934 (Pollini 1988; Astarita 2012 [2000], 105). In this case, the principle of collective creation assumes a new dimension, as it involves an active collaboration not only between two architects, but also between the architects and the client (Pollini 1988; De Seta 2012 [2000], 13-14). We will analyse it here as a notable example of industrial architecture, which in the 1920s and 1930s became increasingly central to the concerns of modernist architects and in particular the rationalist movement. ${ }^{36}$ As De Seta has argued, industrial architecture was crucial to the development of modern architecture in the twentieth century, and the buildings commissioned, and co-designed, by Olivetti from 1934 onwards were among the most significant examples of this genre (De Seta 2012 [2000], 11). ${ }^{37}$ Adriano Olivetti was an engineer and entrepreneur, who saw architecture and urban planning as central aspects of the project of modernization which he had initiated on taking over the family business, a factory producing typewriters, in 1932 (Astarita 2012 [2000], 43). ${ }^{38}$ His modern and enlightened idea of entrepreneurship involved putting the 'financial power and the refined technique' of the enterprise 'at the disinterested service of the social and cultural progress of the territory in which it operates' (Olivetti 1960, 44-45). ${ }^{39}$

In 1926, engineer and architect Gaetano Minnucci authored a long article entitled 'L'architettura e l'estetica degli edifici industriali' in 
Architettura e arti decorative. He celebrated industrial architecture as the most sincere expression of an age in which architecture's task was more and more 'utilitarian' and 'human' ('[...] un compito sempre più utilitario, sempre più umano'). It was, firstly, a form of architecture to which strict rationality 'naturally' applied, involving the suppression of any form of decoration; and secondly, it had a strong social vocation, in that its ultimate goal was improving peoples' working conditions, especially among the working classes (Minnucci 1926). These reasons made industrial architecture central to the concerns of the rationalist movement, and they converged with Adriano Olivetti's ideas. It is therefore not surprising that Olivetti turned to rationalist architects to realize the changes he had in mind. The construction of two new buildings to extend the factory plant—which consisted of a redbrick construction built by Camillo Olivetti, Adriano's father-began in 1934 and lasted around eight years, during which a series of extensions were added (Pollini 1988, 155). The main principle that guided the design of modern industrial buildings was the rationalization of the productive space, accompanied by the need for order and transparency; functional values which, nevertheless, also assumed symbolic meanings. As Walter Gropius, who had designed one of the twentieth century's most emblematic industrial buildings (the Fagus Factory, in Alfeld-an-der-Leine) stated, the architect needed to consider the aesthetic, as well as the technical and practical aspects of designing such buildings. A modern, ultra-rational industrial aesthetic created by architects would not only provide factory workers with light, air, and cleanliness, but also offer them 'a great common ideal' (cited in Astarita 2012 [2000], 35). The purpose was dignifying work and workers, and making them feel part of a great collective project, conferring greater meaning upon a mechanical type of work that risked being monotonous and dehumanizing. A rational, aesthetically pleasing environment would besides materially improving their working conditions, also satisfy an innate aesthetic sense among the workforce (Ibid., 37) (Fig. 7.5).

Figini, Pollini and Olivetti himself applied these principles in designing the extension to the Olivetti factory. Scientific management theories influenced the layout of the working space, which followed the production line according to functionalist principles (Astarita 2012 [2000], 36). ${ }^{40}$ 


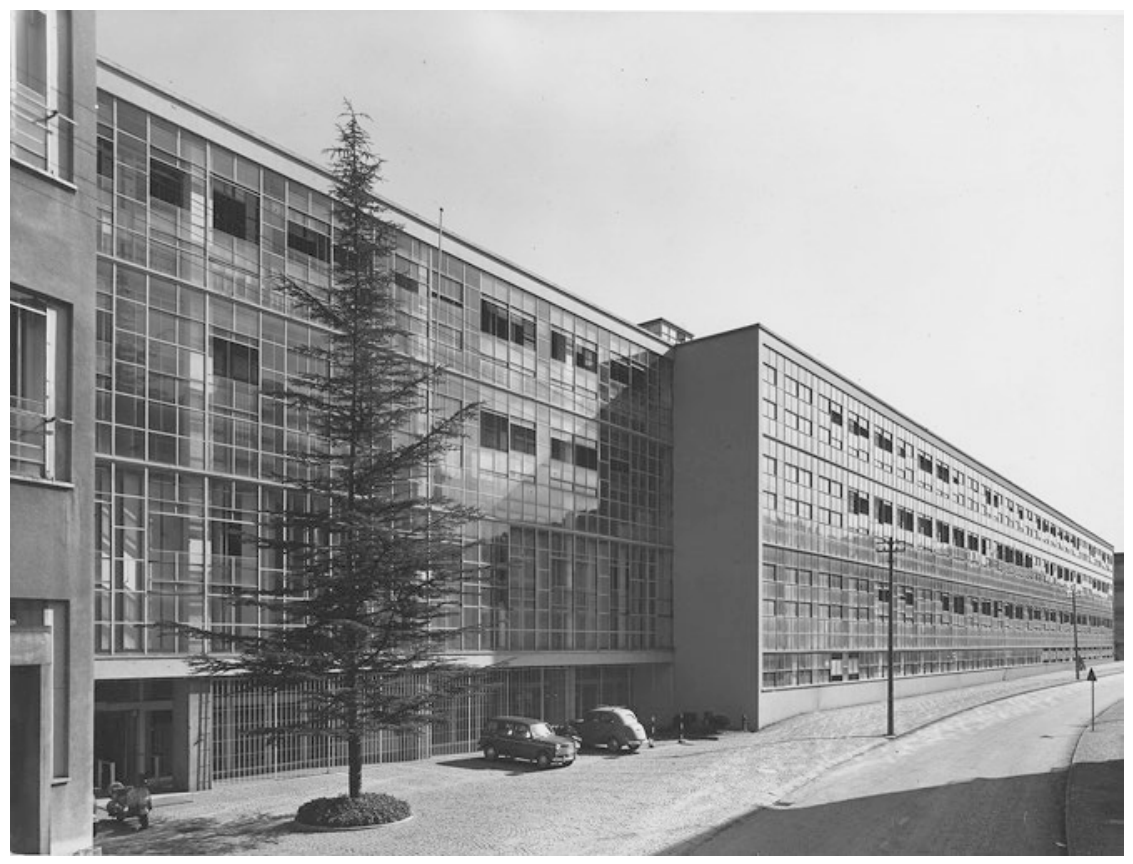

Fig. 7.5 Luigi Figini e Gino Pollini, Ampliamento delle Officine Olivetti a Ivrea, fronte lungo via Jervis, 1939-1940

As far as the structure was concerned, the architects rejected 'the typology of the workshop enclosed by walls' ('la tipologia dell'officina chiusa da muri') creating a barrier between the inside and the outside (Pollini 1988, 156). Simple reinforced concrete or steel frames were used, applying a rationalist aesthetic based on pure functionality and the visibility of the construction methods employed, bestowing aesthetic value upon the very materials and structural elements used in the building. The use of steel frames was also instrumental to the inclusion of a key element of modern architecture, large windows, which became the symbol of the Olivetti factory. The architects, encouraged by Olivetti himself, opted for a fully glazed façade, never before built in Italy (Pollini 1988, 156; Astarita 2012 [2000], 107). Large windows enabled functional lighting and were essential in the model of the 'daylight factory', which exploited enhanced natural lighting throughout the working day, and symbolically 
represented the factory's transparency, cleanliness, openness and hygienic character. Concrete and glass, white plaster and flat roofs contributed to the creation of the rational and ultra-modern image of the factory formulated by Gropius, which from that moment on became a trademark of Olivetti and his enlightened entrepreneurial model.

In 1935, Olivetti enlisted Figini and Pollini again, and with them devised a plan for a new working-class district near the factory, in Ivrea. After the initial project of modernizing and rationalizing the factory space, he began planning building projects and infrastructure centred on the factory, but reaching outwards to shape the surrounding area. This practice ensued from his belief that the presence of a factory should positively impact upon its context, and generate social and cultural change. This enlightened agenda marked all of Olivetti's subsequent endeavours, creating classic examples of the virtuous synergy of industrial and socialcultural development, up until his death in 1960 (see Ghirardo 2013, 155-58). Olivetti intended to promote and create a 'qualitative social architecture that was initially private, but was naturally projected into the public dimension' (Pampaloni 1980, 24). We find, therefore, in his understanding of industrial and social architecture, and chiefly in the building analysed here, an embodiment of the crucial artistic ideal of the morality of architecture and its social function, achieved through the rationalization of aesthetic languages. This was one of the main principles that formed the intersection between developments in architecture and the novel in the Fascist period, and characterized the novels analysed in the previous section, in particular Luce fredda and the Fiat novels.

Olivetti's enlightened ambitions converged with the rationalist belief not only in the social function of architecture, but in its power to act upon reality and change it radically, wherein lay its moral potential. The goal of these projects was not only to provide factory workers with a modern and healthy work environment, but also improve their living conditions more generally. Olivetti also believed that these improvements should not only concern factory workers, but also spill over to benefit the surrounding areas and communities, so that the factory could become a factor of positive change beyond itself and its workforce. This was a 'total' conception of architecture as an intervention upon reality, which included producing urban plans and building innovative industrial architecture, 
but also blocks of housing and infrastructure (such as kindergartens or primary schools). The meanings and functions of 'architecture' associated with the factory thus expanded to include processes of the formation and shaping of collective spaces, and the veritable creation of 'moral' communities. Through the rationalization and enhancement of the working space and the living environment, rational architecture could stimulate the adoption of healthy, virtuous lifestyles and a new morality, fostering collective welfare and social improvement.

This understanding of architecture as an instrument of social engineering and community creation through the management of the collective space was of course, in the 1930s, very much aligned with the social goals of the regime and the accomplishment of the Fascist 'revolution'. Olivetti embraced some aspects of the regime's economic and artistic policies, in particular in the field of urban planning, where he saw the regime as a strong central power which could directly implement the necessary transformations in urban areas, following the model of 'corporativist urbanism'. ${ }^{41}$ In 1935 he wrote an article entitled 'Razionalizzazione e corporazioni' which was published in Il lavoro fascista and Quadrante (Olivetti 1935), in which he stated the need to establish a centralized institute for construction and urban planning. He claimed that since 'new urban planning must be the most obvious expression of the Fascist revolution', the centralization and standardization of directives would be instrumental in the creation of a 'style, an architecture and urban planning of the Fascist era, in their material expression' (Olivetti 1935, 6). ${ }^{42}$ In 1936 Olivetti met with Mussolini to discuss the aforementioned project for a working-class district in Ivrea. Gino Pollini, one of the project's designers, mentioned the project and the meeting in a letter to Bardi: '[...] houses for about 3000 people near the Olivetti factory [...] an organic complex of a functional and corporativist city that Olivetti wants to take to [Mussolini], because the project cannot be realized without financial assistance' (cited in Tentori 1990, 129). ${ }^{43}$ The project was presented in Casabella in 1936, in an article entitled 'Architettura al servizio sociale' (no. 101: 4-5). Pagano, as well as reviewing it very positively, inserted a special card in the copies of this issue after printing, which announced that the project had pleased the Duce (Astarita 2012 [2000], 48). The Olivetti factory complex thus realized the Fascist 
ambition of an art that could shape socially modernized and rationalized communities, an ambition which was projected onto both architecture and the novel.

\section{The Danteum: The Construction of Imperial Myth}

In 1938, architects Giuseppe Terragni and Pietro Lingeri received a commission to design the 'Danteum', a 'temple' to Dante Alighieri to be erected in Rome, which would function as a 'National Organization' including a library and a museum (from Valdameri's 1938 Statute of the Danteum, reprinted in Schumacher 1983, 145-146, and Schumacher 2004, 153). The initiative came from Rino Valdameri, the Director of the Royal Brera Academy in Milan, who was a great lover of Dante and a convinced Fascist since the March on Rome (Schumacher 2004, 36). He proposed this idea to Mussolini and obtained financial support from industrialist Alessandro Poss, who offered to contribute 2 million lire. ${ }^{44}$ The site designated for the building, on Via dell'Impero, and apparently chosen by Mussolini himself (Marazzi 2015, 65), had a high symbolic value, having originally been selected for the Palazzo del Littorio in the 1934 competition, which Terragni and Lingeri had entered (see Chap. 4). The two architects prepared a set of drawings of the Danteum and presented them to Mussolini in November 1938, during an audience to which Valdameri and Poss were also invited (Schumacher 2004, 36). Mussolini approved of the project, and decided it should be built in time for the Exposition of 1942 (E42). However, the Danteum suffered the same fate as many other E42 buildings, and never saw the light of day, owing to the outbreak of war. Giuseppe Terragni drafted a Relazione sul Danteum to accompany the drawings, which is key to reconstructing the design of the building as well as the intentions and meanings attached to it (reprinted in Schumacher 1983, 135-144, and translated in Schumacher 2004, 127-50). ${ }^{45}$ Terragni envisioned the Danteum as a 'translation' into architectonic terms of the Divine Comedy. Unlike the other buildings analysed here, the Danteum, rather than exemplifying a convergence between Fascist architecture and the novel in terms of theoretical, 
conceptual and structural principles, instead constitutes a unique formal, spiritual and symbolic 'encounter' between literature and architecture, glorifying the Fascist imperial ideal. For this reason, and also on account of its time frame, which covered the regime's final phase, we have chosen to conclude our book with it.

Within the modern movement, Terragni was the chief exponent of a strand that believed architecture should be the expression of ideals, proportions, and pure forms:

Architecture is not simply construction, or even satisfaction of material needs; it must be something more [...]. Only when a harmony of proportions is reached, inducing the observer to pause in contemplation or emotion-only then will the constructive scheme have become a work of architecture. (Terragni 1931) 46 $^{4}$

For Pagano, however, architecture was strictly functional and constituted the primary means through which the social and cultural revolution of the Fascist regime would be accomplished. It embodied the morality of the Fascist ideal and of the Fascist revolution, and was strictly anti-rhetorical. For Terragni, architecture ought to represent the order, purity, and rationality of the Fascist ideal (exemplified by the famous statement 'Fascism is a house of glass', referring to Como's Casa del Fascio), which corresponded to the supreme harmony of pure art and to the superior laws of architecture, and thus had an educational function, helping the masses to recognize, receive, and internalize this ideal. The difference here was between an understanding of modern architecture as the style of a modern state as opposed to the image of a spiritual regime; architecture as a moral form versus an ideal form (Ciucci 2002 [1989], 144-49; see also Chap. 4). However, the two models shared the principle of aesthetic rationalization, and of the collective function and objectives of architecture (Fig. 7.6).

The Danteum is an emblematic expression of the conception of architecture upheld by Terragni. The project was not grounded in the same principles of adherence to reality, functionality, utilitarianism, and modesty identified in the previous buildings analysed here, although its architectural language is distinctly rationalist. In the Relazione, Terragni stated 


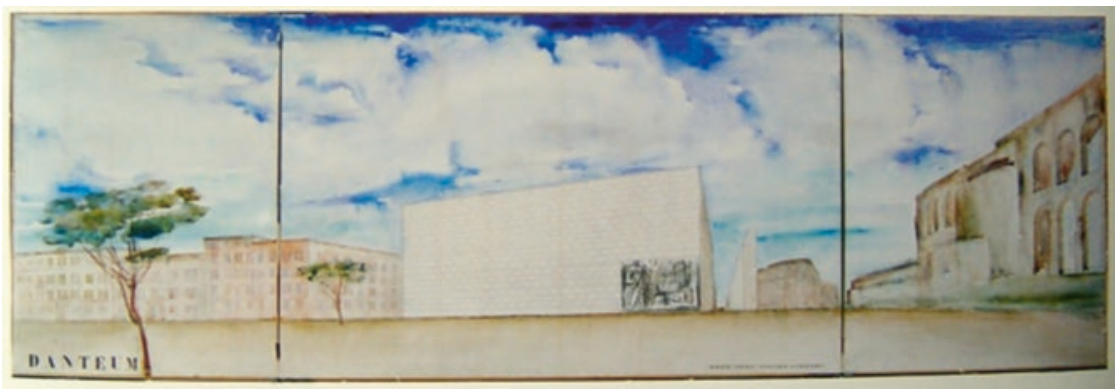

Fig. 7.6 Progetto per il Danteum, view towards the Colosseum, 1938, Archivio Pietro Lingeri

that the project sought to confront and explore universal 'aspects of spiritual life' that modern architecture had hitherto avoided. These were defined by the words 'monumentalism', 'symbolism', and 'solemnity' ('monumentalità, 'simbolismo' e 'aulicità), and were seen as particularly relevant to the Danteum because they defined the architectural environment in which it would be built, with the ruins of the Imperial Fora, the Basilica of Maxentius, and the Colosseum unequivocally conveying the legacy of Imperial Rome. These were indeed concepts that were largely alien to the architectonic language and ideas embraced by the rationalists, and were 'laden with dangers and equivocations'. According to Terragni, only a 'synthesis' of - and not a compromise between - modern architecture (seen as functional, spontaneous and pure) and these 'universals' of architecture could resolve this confrontation (Schumacher 2004, 128). The correspondence that he established between the Divine Comedy and the Danteum was symbolic, formal and spiritual. The Danteum was conceived as a celebration of the most illustrious Italian poet, taken as a symbol of the nation's literary genius, of the imperial ideology that the regime had revived and appropriated, and of Italy's unification and the construction of its national identity, to which Dante's artistic endeavours had made a fundamental contribution. However, Dante's poem itself was seen as a construction based on a well-defined composition relying on rhythmic patterns, symbolic numbers, geometry and proportions, which could be recreated as spatial and architectural factors determining the relationships between dimensions, spaces, and volumes in a building. As 
Terragni wrote in the Relazione, the Danteum's purpose was to 'express through architectural harmony the marvellous philosophical and poetic "construction" of the most important spiritual declaration that humanity can claim', namely the Divine Comedy (Relazione, Schumacher 2004, 127) (Fig. 7.7). ${ }^{47}$

Terragni's starting point for the project was the golden rectangle, which he considered to be a symmetrical structuring principle analogous to that governing the structure of the Divine Comedy (based on the numbers 1, $3,7,10$ ), as well as the 'value of "Absolute" geometric beauty' ('valore di "Assoluta" bellezza geometrica') (Relazione, Schumacher 2004, 130; 1983 , 135), thus inextricably linking his project to classical architecture and to the surrounding ruins. Indeed, the long side of this rectangle forming the floor plan of the Danteum was equal to the short side of the adjacent Basilica of Maxentius, establishing a direct relationship with the temple's illustrious surroundings. Over the golden rectangle were superimposed two partially overlapping squares. The internal divisions and proportions of the building's rooms were also derived from the decomposition of the golden rectangle, bringing the idea of the 'infinite' into the project, as well as the numbers one and three: the golden rectangle

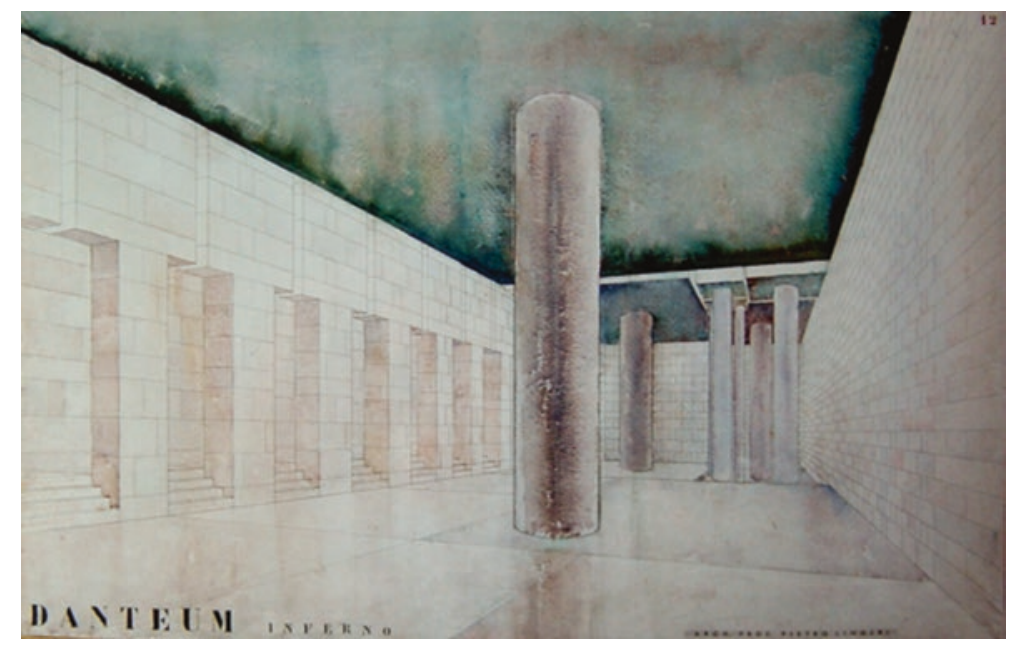

Fig. 7.7 Progetto per il Danteum, Inferno, 1938, Archivio Pietro Lingeri 
'expresses the harmonic law of unity in trinity' because 'one is the rectangle, three are the segments that determine the golden ratio' (Relazione, Schumacher 2004, 131). ${ }^{48}$ The building was divided into three main rectangular rooms, representing Inferno, Purgatory, and Paradise, preceded by two square areas: an open court, and an area with a hundred marble columns. The courtyard was intentionally 'wasted' from a planning point of view, alluding to the perdition of Dante's worldly life, while the following space represented the 'forest' where Dante's journey starts. ${ }^{49}$ In the rooms representing the three canticles, Terragni aimed to establish a spiritual and 'emotional' correspondence with the poem through spatial and plastic elements, recreating 'mythical' atmospheres that would cause visitors to feel the emotions evoked by Dante, rather than mimetically reproducing elements recalling the plot, characters or settings (which also enabled Terragni to observe a strict anti-decorativism). Thus, for instance, in the Inferno room, the

fractured ceiling and the floor, which is decomposed into diminishing squares, the scanty light that filters through the cracks in the blocks in the ceiling, all will give the catastrophic sensation of pain and useless aspiration to gain the sun and light. (Relazione, in Schumacher 2004, 146-47) ${ }^{50}$

Paradise, by contrast, was an ethereal and luminous space filled with 33 glass columns supporting a transparent frame, giving a view of the sky and conveying a sensation of otherworldly peace. It was this recreation of spiritual atmospheres and the emotional response that Terragni sought to elicit in visitors which 'endow[ed] the building with mythical values and

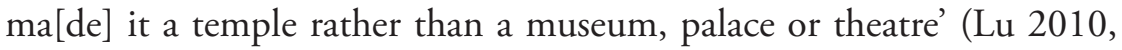
240) (Fig. 7.8).

This conception of the building as a creation and an embodiment of myths, the 'primordal' emotions that it should elicit in the audience, as well as the intersection of architecture and literature constructed through two overlapping and intercommunicating artistic forms, are clearly reminiscent of Bontempelli's theories of modern art and magical realism (see Chap. 5). In the second paragraph of the Relazione, Terragni included a sentence which was virtually a quotation from Bontempelli's well-known programmatic statement on rationalist and anti-rhetorical art: 


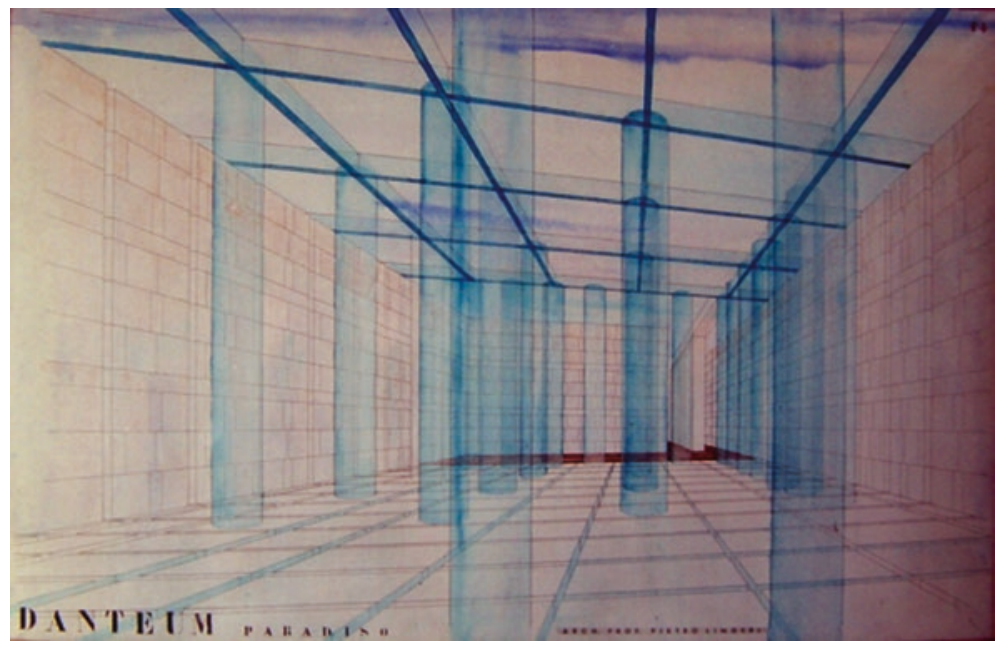

Fig. 7.8 Progetto per il Danteum, Paradiso, 1938, Archivio Pietro Lingeri

Glorifying a great man by honoring that work of his which was called Divine $[\ldots]$ means that the maximum of expression is to be obtained with the minimum of rhetoric, the maximum of emotion with the minimum of decorative or symbolic adjectives. It means to create a great symphony with elemental means. (Relazione, in Schumacher 2004, 127) ${ }^{51}$

Bontempelli, who was Terragni's friend, certainly had an influence on the architect's reflections on literature and architecture as two intercommunicating aesthetic languages, and had a role in the events surrounding the design of the Danteum. He was the first person to read the Relazione, given to him by Lingeri, and which he passed on to to Marino Lazzari, general director of Antiquities and Fine Arts, who in turn discussed it with Bottai (Marazzi 2015, 72). Some scholars have even speculated that he made changes or interventions to the draft of the Relazione (Milelli 1996, 571). As has already been argued, this solemn crystallization of myths realized the building's political function, which consisted in rooting Mussolini's imperial project in the ideas and endeavours of one of the most eminent Italian poets and political thinkers, building a veritable foundational myth (Fig. 7.9). 


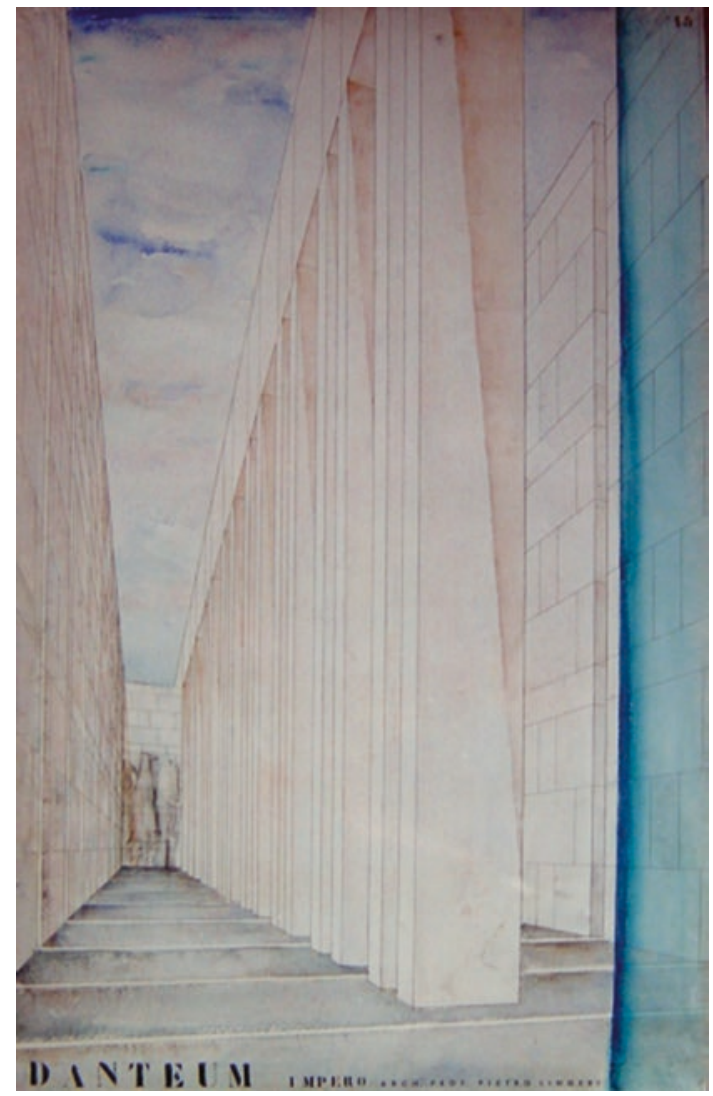

Fig. 7.9 Progetto per il Danteum, Impero, 1938, Archivio Pietro Lingeri

This mythopoeic function found a powerful expression in the Empire room, a long corridor-like room that was supposed to end the visitor's itinerary. Terragni defined this space 'of fundamental spiritual importance' ('di fondamentale importanza spirituale') because 'it comes to represent the germ of the architectural whole' ('viene [...] a rappresentare il nocciolo dell'organismo costruttivo'), and was equivalent to the 'central nave of a temple' ('la navata centrale del tempio). The room was a tribute to the 'universal Roman Empire that was envisaged and forecast by Dante as the ultimate purpose and the only remedy for saving humanity and the Church from disorder and corruption' (Relazione, Schumacher 2004, 
138-39). ${ }^{52}$ At the end of this space loomed the image of an eagle, the perfect symbol encapsulating the meanings, concepts and figures that the building sought to glorify and perpetuate. The eagle is the symbol of imperial justice, and in Canto XVIII of Paradise it appears as a transformation of the last letter of the phrase Diligite Justitiam Qui Judicatis Terram (He who rules the earth must administer justice); it is also, of course, the first letter of the name Mussolini, which the Duce often used as a signature (Schumacher 2004, 121). It thus fulfilled the project's overall purpose of giving a plastic-architectonic form to myths and symbols drawn from the repertoire of the national literary tradition in order to bolster Fascist imperial ideology. From the foundational literary work of the national canon, Terragni drew a principle of order and symmetry which, when turned into an architectonic principle, could embody the ideal of geometric harmony based on pure forms which he wished to express in his rationalist architecture, and at the same time function as the symbol of the illustrious roots of the Fascist imperial myth.

\section{Conclusion}

Like the novels analysed in the first section of this chapter, the buildings examined here embody the principles that constitute structural links between architecture and the novel taken as two aesthetico-political endeavours working towards the construction of a Fascist culture and the cultural and social modernization of the nation. Florence railway station is an emblem of modernity in a utilitarian building, which represents both the modernizing mission of the regime and the anti-rhetorical revolution of the modern movement. At the same time, it marked the high-water mark for the Rationalist front in their ultimately vain battle for hegemony within the Fascist aesthetic system. The station had been built according to principles of functionality and anonymity that were central to both new architecture and the new novel. The expansion of the Olivetti factory also exemplifies the principles of anonymity and collective production, as well as epitomizing the morality of modern, specifically industrial and social architecture, which was achieved through the rationalization of space, both public and private. Finally, the Danteum 
constitutes a unique example of interconversion between architecture and literature, on the basis of symbolic, formal, and spiritual principles, which ultimately serves the purpose of contributing to the creation of national myths for the regime, and glorifying Fascism's imperial ideology.

\section{Notes}

1. 900 published the short stories La cortigiana stanca, translated into French as Lassitude de courtisane, in 1927 (2, no. 3 [Spring], pp. 13445); Caverne: doppio uso; Delitto al circolo del tennis; and Caverne in 1928 (respectively 3, no. 1 n.s. [July]: 44-45; 3, no. 3 n.s. [September]: 12531; and 3, no. 6 n.s. [December]: 284-85); Il ladro curioso and Apparizione in 1929 (4, no. 1 [January]: 18-26 and 4, no. 5 [May]: 215-22).

2. I lupi published Dialogo tra Amleto e il principe di Danimarca in 1928 (1, no. 3 [29 February]: 3). Interplanetario published Cinque sogni, Assunzione in cielo di Maria Luisa, Albergo di terzordine, and Villa Mercedes, all in 1928 (respectively 1, no. 2 [15 February]: 3; 1, no. 4 [15 March]: 2; 1, no. 5 [1 April]: 3; 1, no. 7-8 [1 June]: 4).

3. This is the only article that Moravia signed using his real name, Alberto Pincherle. It was reprinted in Voza 1982, 210-12.

4. '[...] mi ero messo in mente di scrivere un romanzo che avesse al tempo stesso le qualità di un'opera narrative e quelle di un drama. Un romanzo con pochi personaggi, con pochissimi luoghi, con un'azione svolta in poco tempo. Un romanzo in cui non ci fossero che il dialogo e gli sfondi e nel quale tutti i commenti, le analisi e gli interventi dell'autore fossero accuratamente aboliti in una perfetta oggettività. [...] D'altra parte mi ero convinto che non mettesse conto di scrivere se lo scrittore non rivaleggiava col. Creatore nell'invenzione di personaggi indipendenti, dotati di vita autonoma.'

5. Mussolini's own appraisal of the novel, revealed to Mussolini's biographer Yvon De Begnac, was rather ambiguous: 'a novel that is obscenely bourgeois and antibourgeois at the same time, written by the nephew of a union official friend of mine, De Marsanich, the son of a sister married to a Jewish engineer, Pincherle. That book, the debut novel of a young author, written in mediocre Italian but powerful in describing a Roman environment which I would not have suspected could still survive, 
disclosed to me the presence of real antifascism, an antifascism that does not speak, does not reveal its presence.' '[...] Un romanzo oscenamente borghese e antiborghese al medesimo tempo, dovuto al nipote di un mio amico sindacalista, De Marsanich, figlio di una sorella maritata a un ingegnere ebreo, Pincherle. Quel libro, opera prima di un giovanissimo, scritta in mediocre italiano, ma potente nel raccontare un ambiente romano del quale mai avrei sospettato la sopravvivenza, mi aveva svelato la presenza del vero mondo dell'antifascismo, dell'antifascismo che non parla, che non rivela la propria presenza.' (De Begnac 1990, 483-84).

6. An artistic, and specifically literary, tendency inspired by the life and works of Gabriele D'Annunzio, marked by aestheticism, decadentism, and a flamboyant and flowery style.

7. See for instance the articles 'Un'estetica nuova per un'arte nuova' (1927a), 'Considerazioni sul romanzo' (1932), and 'La mia fede' (1933), reprinted in Barbaro 1976, 75-84; 132-38; and 139-41.

8. 'Futuristi, suprematisti, cubisti, espressionisti, surrealisti, costruttivisti, realisti, avanguardisti, tutti con il MOVIMENTO IMMAGINISTA!'.

9. '[...] per un comune modo di vedere la realtà e per volere rendere creativa e modificare con l'arte questa realtà'.

10. 'La vera moralità dell'arte sta nel ricongiungere, ricostringere nelle angustie della quotidianità il lettore, per dargli l'ansia insopprimibile di uscire, di farsi migliore, di trasformare sé stesso e il mondo [...].'

11. All quotations refer to the 1990 edition of Luce fredda (Montepulciano: Editori del Grifo).

12. 'A volerla in nuce la mia estetica si riduce a un problema di rapporti tra arte e vita.'

13. '[...] I valori formali e tecnici, nella cui sfera sono rimasti fin ora quasi tutti i modernisti, sono [...] in armonia con un ricco ed. elevato contenuto.'

14. See, for instance, p. 197, where the characters' thoughts and actions are mixed up and it is not clear even to them whose point of view they are expressing.

15. 'Il tentativo di conciliare anche nell'arte i due termini, individuo e società, e quindi il singolare e il molteplice, vuol trovare una soluzione in una letteratura aderente alla vita e che superi il romanzo tradizionale, biografico e psicologico, per divenire il racconto di fatti collettivi oppure proiezione sulla massa di fatti individuali: il romanzo collettivo dovrebbe quindi essere romanzo sociale o corale.' 
16. See, for example, the article ' $E$ io ti dico che non è più un genere di lusso' ('And I tell you it is no longer a luxury product') from a 1924 issue of Rivista Fiat. This text represents the new popular image of the car as a consumer product, which Fiat sought to establish in this period (reprinted in Tongiorgi 1994b, 423-26).

17. 'Qui siamo ben lungi dalla enfatica scoperta della velocità cui la letteratura andata-dal bello e orribile mostro carducciano alle avanguardie velociste d'anteguerra—ci aveva abituati. Anzi, qui dentro la velocità non la senti più: questa è la scoperta estetica, intima e veramente importante, delle avventure semplici di Filiberto. [...] Così si smantella l'assurdo retorico della velocità come fatto assoluto.'

18. 'Perché tutto il movimento dell'architettura nuova è nato dal fatto che s'è cominciata a vedere la città non come una serie di contemplazioni ferme [...], ma quale il prodotto del movimento che gli uomini compiono nelle sue vie.'

19. '[...] passò dalla considerazione della sua pigrizia alla considerazione della vita rinnovata che lo circondava'.

20. 'Con la gioia nuova dell'automobile rivedeva le sue posizioni mentali. S'era fissato che al volante, solo, correndo per le strade, conquistando distanze e libertà di movimento, avrebbe potuto pensare [...]'.

21. 'Filiberto non ragionava più come una volta all'insegna del giudizioso principio di rispettare le idee e gli interessi della maggioranza [...]. Il suo ragionamento s'era sveltito, procedeva sincopato, veloce e conclusivo. Il volante gli dava una personalità nuova al confronto con gli altri'.

22. ' [...] Erano tutti gli ingegneri, erano tutti i tecnici, erano tutti gli operai in comunione di idee, in disciplina di lavoro, in quotidiana aspirazione di raggiungere il meglio [...]'.

23. 'Cafarnai assurdi, stracarichi di suppellettili avariate e di carabattole inutili e di pessimo gusto... Che idee possono nascere in simili ambienti, che anime ci si possono formare? La casa dovrebbe essere tutta di cemento, vetro, di porcellana: limpida, pulita, trasparente: in modo da provocare in chi l'abita l'amore per l'ordine, l'organizzazione, la rapidità, la decisione, l'equilibrio; per tutti quelli che sono requisiti indispensabili di una vita dignitosa.'

24. See, for instance, Alberto Sartoris, 1929, 'Architettura standard'. La Casa Bella 23 (November): 10; Enrico A. Griffini, 1932. Costruzione razionale della casa. Milan: Hoepli; and Giuseppe Pagano, 'Le costruzioni in serie'. Casabella-Costruzioni 144 (December): 2. 
25. 'Costruite a serie e mandate l'arte al diavolo! Standardizzate, taylorizzate... frantumate i vasetti, i ninnoli, i quadri e tutte le altre porcherie ... O per lo meno raschiate fino allo scheletro questi abituri polverosi e maledetti! Che non facciano schifo di fuori e che dentro ci si possa lavorare, riposare, godere; ci si possa concepire l'idea di un futuro più sano, più pulito! Ė proprio vero che l'architettura è un'arte sociale!... Ma vallo un po' a dire a questi ciarlatani di architetti!'

26. 'Ma il caldo e l'animosità tradivano le sue stesse convinzioni deformandole. Alla fine Sergio sorrise della sua solita sfuriata. In fin dei conti ci si adatta [...] e questo è l'atroce. Che ci si adatta, che questa insofferenza è momentanea, passeggera...'

27. 'Quando sarebbe ritornato dal suo viaggio, avrebbe cambiato lo studio: gettato a mare i mobili stile Cinquecento, strappate le tendine a punto Verona, spazzato il calamaio neo-classico: via l'odor di muffa, di stantio, di notarile.'

28. See, for example, the Gruppo 7 Manifesto, published across several articles in La rassegna Italiana between December 1926 and May 1927, partially reprinted in Patetta 1972, 119-32; 'L'architettura e l'estetica degli edifici industriali' by Gaetano Minnucci (1926); and 'Architettura industriale in Italia' by Giuseppe Pagano (1939). See also Rifkind (2012, 24) and Antonucci (2014, 44-45).

29. 'L'architettura italiana sarà tanto più nazionale quanto più andrà verso il popolo.'

30. '[...] quei concetti morali che fanno della nuova Italia corporativa una nazione di soldati che non amano le mollezze del fasto né le lusinghe delle adulazioni.'

31. '[...] serena e colorita, sobria e persino militare, rispecchiante i caratteri di robustezza e d'ordine che sono le preferenze precipue degli Italiani [sic] di Mussolini [...]'.

32. For a detailed analysis of Mazzoni's projects, see Giacomelli 2003. Although his project for the station was rejected, Mazzoni did design the heating plant and main control cabin, recognized as a masterpiece of Futurist architecture (see Pieri 2003).

33. Reconstructions of the controversy can be found in De Seta 1998, 165; Mariani 1989, 212-19; Conforti et al. 2016, 11-19.

34. '[...] tengo a precisare in maniera inequivocabile che io sono per l'Architettura moderna [...] è assurdo non volere un'architettura Razionale e Funzionale del nostro tempo. Ogni epoca ha prodotto la sua 
architettura funzionale.' The speech, entitled 'Non avere paura di avere coraggio', has been reprinted in Carli 1980, 95-96. Translation by David Rifkind (2012, 161).

35. For a detailed account of the debate around Florence railway station on L'Ambrosiano, see Tentori (1990, 284-350).

36. For an exhaustive examination of the development of industrial architecture in Italy, see Parisi 2011.

37. Another emblematic building which predates this period is the Fiat Lingotto factory (1914-1926). It became legendary among modernist architects of the Fascist period, and was even, famously, celebrated by Le Corbusier (De Seta 1998, 122-24; Astarita 2012 [2000], 26-27; see also Pozzetto 1975; Olmo 1994).

38. On Adriano Olivetti and his crucial role in Italian culture see Astarita (2012 [2000], 42-64), Pampaloni (1980), and Fabbri and Greco (1988).

39. '[... la sua potenza finanziaria e la sua raffinata tecnica al servizio disinteressato del progresso sociale e culturale del territorio in cui opera'.

40. Olivetti significantly contributed to the circulation of Frederick Taylor's scientific management theories, and their application in Henry Ford's factories, in Italy, publishing them in his journal Tecnica e organizzazione. For Olivetti, however, these represented a starting point of his 'modern project', and not a goal in themselves, as his real aspiration was the eradication of the dehumanizing aspects of factory work and the assembly line (Astarita 2012 [2000], 62).

41. Corporativist urbanism was mainly theorized in Quadrante as an attempt to synthesize rationalist planning principles with the economic organization of the corporativist state (Rifkind 2012, 264). See, for example, Gaetano Ciocca and Ernesto N. Rogers, 1934, 'La città corporativa'. Quadrante 2, no. 10 (February): 25; Ludovico B. Belgioioso and Gian Luigi Banfi, 1934, 'Urbanistica corporativa'. Quadrante 2, no. 16-17 (August-September): 40; Gian Luigi Banfi, Ludovico B. di Belgioioso, Enrico Peressutti, and Ernesto N. Rogers, 1935, 'Urbanistica corporativa'. Quadrante 3, no. 23 (March): 20.

42. 'L'urbanistica nuova dev'essere l'espressione più evidente della Rivoluzione fascista. Una progressiva centralizzazione di direttive in materia potrebbero realizzare l'armonia e la coordinazione degli sforzi latenti enormi fatti oggi troppo individualmente e spesso con insufficiente coscienza artistica e tecnica per creare nella sua espressione materiale uno stile, un'architettura, un'urbanistica del tempo fascista.' 
43. '[...] abitazioni per circa 3000 persone, nei pressi della fabbrica Olivetti [...] un complesso organico di città funzionale e corporativa [con il quale] Olivetti vuole andare dal Capo del Governo [...] perché la cosa non potrà essere realizzata senza un contributo [...]'.

44. For a close analysis of the network of relationships and connections underlying the project, see Marazzi (2015, 25-35).

45. The version of the Relazione reprinted and translated in Schumacher 2004 includes a part, at the beginning, which was missing from the previous Italian version, published in Schumacher 1983. This part (the so-called giustificazione teorica) was only found in 1986 by Giorgio Ciucci and Silvio Pasquarelli in a document conserved at Rome's Archivio Capitolino, and first published in Casabella 522 (March 1986), pp. 40-41.

46. 'L'architettura non è costruzione e neppure soddisfazione di bisogni d'ordine materiale; è qualcosa di più $[. .$.$] . Quando si sarà raggiunta$ quella "armonia" di proporzioni che induca l'animo dell'osservatore a sostare in una contemplazione, o in una commozione, solo allora allo schema costruttivo si sarà sovrapposta un'opera di architettura'. Translation by Rifkind $(2012,27)$.

47. '[... esprimere in una armonia architettonica la meravigliosa "costruzione" filosofica e poetica della più importante manifestazione dello spirito che l'umanità può vantare [...]' (Ciucci and Pasquarelli 1986, 40).

48. 'Uno è il rettangolo tre sono i segmenti che determinano il rapporto aureo' (Relazione, Schumacher 1983, 136).

49. For a detailed description and analysis of the building layout see Terragni's Relazione (Schumacher 2004, 127-50, 31-59); and Milelli (1996).

50. '[...] questo soffitto fratturato e il pavimento pure scomposto in riquadri digradanti, la scarsa luce che filtra attraverso le fenditure dei blocchi di copertura daranno quella sensazione di catastrofe di pena e di inutile aspirazione verso il sole e la luce [...]' (Relazione, Schumacher 1983, 143).

51. 'Glorificare un grande valendosi dell'esaltazione di una sua opera che fu definita divina [...]. Si tratta di ottenere il massimo di espressione col. minimo di retorica, il massimo di commozione col. minimo di aggetivazione decorativistica o simbolistica. E una grande sinfonia da realizzare con gl strumenti primordiali (Ciucci and Pasquarelli 1986, 40).

52. 'L'Impero Universale e Romano quale fu intravisto e preconizzato da Dante è lo scopo ultimo e l'unico rimedio per salvare dal disordine e dalla corruzione l'umanità e la Chiesa' (Relazione, Schumacher 183, 139). 
Open Access This chapter is licensed under the terms of the Creative Commons Attribution 4.0 International License (http://creativecommons.org/ licenses/by/4.0/), which permits use, sharing, adaptation, distribution and reproduction in any medium or format, as long as you give appropriate credit to the original author(s) and the source, provide a link to the Creative Commons licence and indicate if changes were made.

The images or other third party material in this chapter are included in the chapter's Creative Commons licence, unless indicated otherwise in a credit line to the material. If material is not included in the chapter's Creative Commons licence and your intended use is not permitted by statutory regulation or exceeds the permitted use, you will need to obtain permission directly from the copyright holder.

(c) (i) 